Article

\title{
Environmental Assessment of Ultra-High-Performance Concrete Using Carbon, Material, and Water Footprint
}

\author{
Husam Sameer ${ }^{1,2, *}$, Viktoria Weber ${ }^{1,2}$, Clemens Mostert $^{1}{ }^{(D)}$, Stefan Bringezu ${ }^{1}$ (D), \\ Ekkehard Fehling ${ }^{3}(\mathbb{D})$ and Alexander Wetzel ${ }^{3}$ \\ 1 Center for Environmental Systems Research (CESR), University of Kassel, 34117 Kassel, Germany; \\ vicky191@gmx.de (V.W.); mostert@uni-kassel.de (C.M.); bringezu@uni-kassel.de (S.B.) \\ 2 Faculty of Civil and Environmental Engineering, University of Kassel, 34125 Kassel, Germany \\ 3 Institute of Structural Engineering (IKI), University of Kassel, 34125 Kassel, Germany; \\ fehling@uni-kassel.de (E.F.); alexander.wetzel@uni-kassel.de (A.W.) \\ * Correspondence: husam.sameer@uni-kassel.de; Tel.: +49-561-804-6150
}

Received: 18 February 2019; Accepted: 6 March 2019; Published: 13 March 2019

\begin{abstract}
There is a common understanding that the environmental impacts of construction materials should be significantly reduced. This article provides a comprehensive environmental assessment within Life Cycle Assessment (LCA) boundaries for Ultra-High-Performance Concrete (UHPC) in comparison with Conventional Concrete (CC), in terms of carbon, material, and water footprint. Environmental impacts are determined for the cradle-to-grave life cycle of the UHPC, considering precast and ready-mix concrete. The LCA shows that UHPC has higher environmental impacts per $\mathrm{m}^{3}$. When the functionality of UHPC is considered, at case study level, two design options of a bridge are tested, which use either totally CC (CC design) or CC enhanced with UHPC (UHPC design). The results show that the UHPC design could provide a reduction of $14 \%, 27 \%$, and $43 \%$ of carbon, material, and water footprint, respectively.
\end{abstract}

Keywords: sustainable buildings; life cycle assessment; construction materials; concrete; durability

\section{Introduction}

The construction industry is recognized as an issue of the global environmental impact [1]. Cement production is responsible for up to $8 \%$ of global greenhouse gas (GHG) emissions [2]. This is because of intensive use of energy for heating requirement of raw materials during manufacturing processes of cement $[3,4]$. Investigating efficiency of material resource use is an increasingly important area in the construction sector [5], according to the enormous increase of the construction minerals extraction [6]. Water use in the construction industry has received considerable critical attention [7] due to its intensive consumption within, for instance, cement manufacturing [8]. Investigating alternative concrete technologies is a continuing concern for defining the contribution to the environmental impact mitigation $[9,10]$.

The innovation of Ultra-High-Performance Concrete (UHPC) is increasingly used [11,12] for its high compressive strength of more than $150 \mathrm{MPa}$ with less mass relative to the compressive strength, and the highest tensile strength of more than $10 \mathrm{MPa}$ [13-15]. UHPC, sometimes addressed as Reactive Powder Concretes (RPC), has superior technical performance, e.g., exquisite granular compactness and premium porosity reduction [16]. Compact Reinforced Composite (CRC) provides the combination of the strength with ductility, which increases the durability and formability of the concrete [17]. The experimental comparison of UHPC with Conventional Concrete (CC) indicated that the strength of the used UHPC is three to four times greater than CC strength [18]. In addition 
to that, UHPC has higher modulus of elasticity, higher tensile strength, and ductility. Even though UHPC is subject to an energy-intensive production process [14] and requires a relatively longer mixing time [19], it could provide a longer service life without costly maintenance measures in comparison with CC [20]. Questions have been raised regarding state of the art of UHPC research works related to its environmental performance.

However, UHPC provides a significant reduction in the ratio of mass to load-bearing capacity [14]. It is problematic to decide for instance whether material resources are efficiently used without defining life cycle wide use of material resources [5,21]. While environmental impacts of a different mixture of CC are intensively researched [22-25], substantial environmental issues, e.g., cumulative raw material used [5,26] and water use [27] are still insufficiently studied [28]. These issues have recently received major awareness [29-33]. There is a general lack of studies on LCA of UHPC, Stengel and Schieß1 [34] investigated environmental impact of three bridges which essentially erected using UHPC in three different countries Canada, Germany, and USA. Randl et al. [35] investigated environmental impacts of concrete using efficient energy hydraulic additives instead of cement in UHPC. Consequently, regarding the presented studies, global warming impact is considered, whereas life cycle wide use of material and water resource are still missing.

Environmental performance of construction materials could be comprehensively described by using LCA [36] based on ISO 14040 and ISO 14044 [37]. Sustainability assessment of natural resources, e.g., water and material resources, is a key aspect of achieving the Sustainability Development Goals (SDG) [38]. Recently, indicators of material resource use, i.e., Raw Material Input (RMI) and Total Material Requirement (TMR), which are within the focus of this article, have been defined as crucial indicators to be considered within sustainability assessment schemes of buildings [5]. In addition, it is highly recommended to use the AWARE (Assessing impacts of Water consumption based on Available Water Remaining) method for the assessment of water footprint [27].

This article systematically investigates carbon, material, and water footprint of UHPC in comparison with CC, aiming to facilitate the decision-making process, undertaken by the construction planners. The footprints are assessed within cradle-to-grave life cycle stages according to EN 15804 [32].

\section{Materials and Methods}

\subsection{Reference Mixtures of Concrete}

Specifications of concrete are regulated in DIN EN 206 [39]. Two mixtures of UHPC, M3Q and $\mathrm{M} 2 \mathrm{Q}$, are selected from the results of a research project within the German priority program 1182 [14], for the ready-mix concrete, $\mathrm{M} 3 \mathrm{Q}$ mixture of $\mathrm{UHPC}$ is considered and for the precast concrete, $\mathrm{M} 2 \mathrm{Q}$ mixture of UHPC is considered. The environmental analysis is done in comparison with two mixtures of CC, ready-mix concrete (C35/45) and precast concrete (C50/60) [40], where 35 and 50 refer to the minimum compressive strength in $\mathrm{MPa}$ of a cylinder specimen of concrete with $150 \mathrm{~mm}$ in diameter and $300 \mathrm{~mm}$ in length, respectively, and 45 and 60 refer to the minimum compressive strength in MPa of a cube specimen of concrete with $150 \mathrm{~mm}$ edge length after 28 days when tested according to DIN EN 206 [39]. Mixtures of CC and UHPC are shown in Table 1.

UHPC is known for its high compressive strength of more than $150 \mathrm{MPa}$ with low water/cement ratio [11]. Schmidt et al. [14] defined the type of cement for M3Q and M2Q as fast hardening Portland cement (CEM I 52.5) with high sulfate resistance and low alkali content of 52.5, which represents the minimum compressive strength at 28 days according to EN 197-1 [41].

For the CC mixtures, the average mixture of concrete in Germany is used as it has been described for the environmental product declarations (EPD) of the concrete by the German Federal Association of Concrete [40]. For the comparison's purposes, quantities of aggregates are defined as primary raw materials by considering the proportion of the recycled aggregate within the quantity of primary aggregate. In order to define type of cement, average content of clinker in cement is 85\% [42], which corresponds to the cement type of CEM II/ A according to EN 197-1 [41]. 
Table 1. Reference mixtures of Conventional Concrete (CC) and Ultra-High-Performance Concrete (UHPC) [14,40].

\begin{tabular}{cccccc}
\hline & & \multicolumn{2}{c}{ UHPC } & \multicolumn{2}{c}{ CC } \\
\cline { 3 - 6 } Material & Unit & Ready-mix & Precast & Ready-mix & Precast \\
\cline { 3 - 6 } & & $\mathrm{M} 3 \mathbf{Q}$ & M2Q & C35/45 & C50/60 \\
\hline Cement/CEM I 52.5 R-HS/NA (SR 3) & $\mathrm{kg} / \mathrm{m}^{3}$ & 775 & 832 & - & - \\
Cement/CEM II/A & $\mathrm{kg} / \mathrm{m}^{3}$ & - & - & 356 & 405 \\
Quartz sand & $\mathrm{kg} / \mathrm{m}^{3}$ & 946 & 975 & - & - \\
Sand & $\mathrm{kg} / \mathrm{m}^{3}$ & - & - & 640 & 654 \\
Gravel & $\mathrm{kg} / \mathrm{m}^{3}$ & - & - & 806 & 827 \\
Grit & $\mathrm{kg} / \mathrm{m}^{3}$ & - & - & 362 & 371 \\
Water & $\mathrm{kg} / \mathrm{m}^{3}$ & 183 & 166 & 165 & 141 \\
Quartz powder & $\mathrm{kg} / \mathrm{m}^{3}$ & 193 & 207 & - & - \\
Silica fume & $\mathrm{kg} / \mathrm{m}^{3}$ & 164 & 135 & - & - \\
Fly ash & $\mathrm{kg} / \mathrm{m}^{3}$ & - & - & 47 & 25 \\
Superplasticizer & $\mathrm{kg} / \mathrm{m}^{3}$ & 23.50 & 29.40 & - & - \\
Plasticizer & $\mathrm{kg} / \mathrm{m}^{3}$ & - & - & 1.80 & 4.60 \\
Micro steel fibers & $\mathrm{kg} / \mathrm{m}^{3}$ & 192 & 192 & - & - \\
Total & $\mathrm{kg} / \mathrm{m}^{3}$ & 2476.50 & 2536.40 & 2377.80 & 2427.60 \\
\hline
\end{tabular}

\subsection{Life Cycle Assessment}

The Life Cycle Inventory (LCI) of UHPC in comparison with CC is described based on the Life Cycle Stages according to EN 15804 [32]. LCI Input and output environmental flows of are shown in Figure 1. The database of GaBi XIV construction materials [43] is used with openLCA software [44] for the LCA modeling for all processes except the production process of steel fibers, which is not available within the GaBi XIV database. Therefore, ecoinvent 3.1 database [45] is used for the LCA modeling of steel fibers. In terms of the comparison at the construction materials level, LCI is described using average values in Germany. Interviews with stakeholders have been conducted for the non-documented data such as transportation distance of quartz sand to the concrete plant. LCI processes are described in Appendices A-C. Secondary materials are allocated according to EN 15804 [32]. Fly ash is a by-product of the coal power station. Silica fume is a by-product of the production of silicon metal or ferrosilicon alloys. Therefore, their environmental impacts are only considered for the transport to the concrete plant.

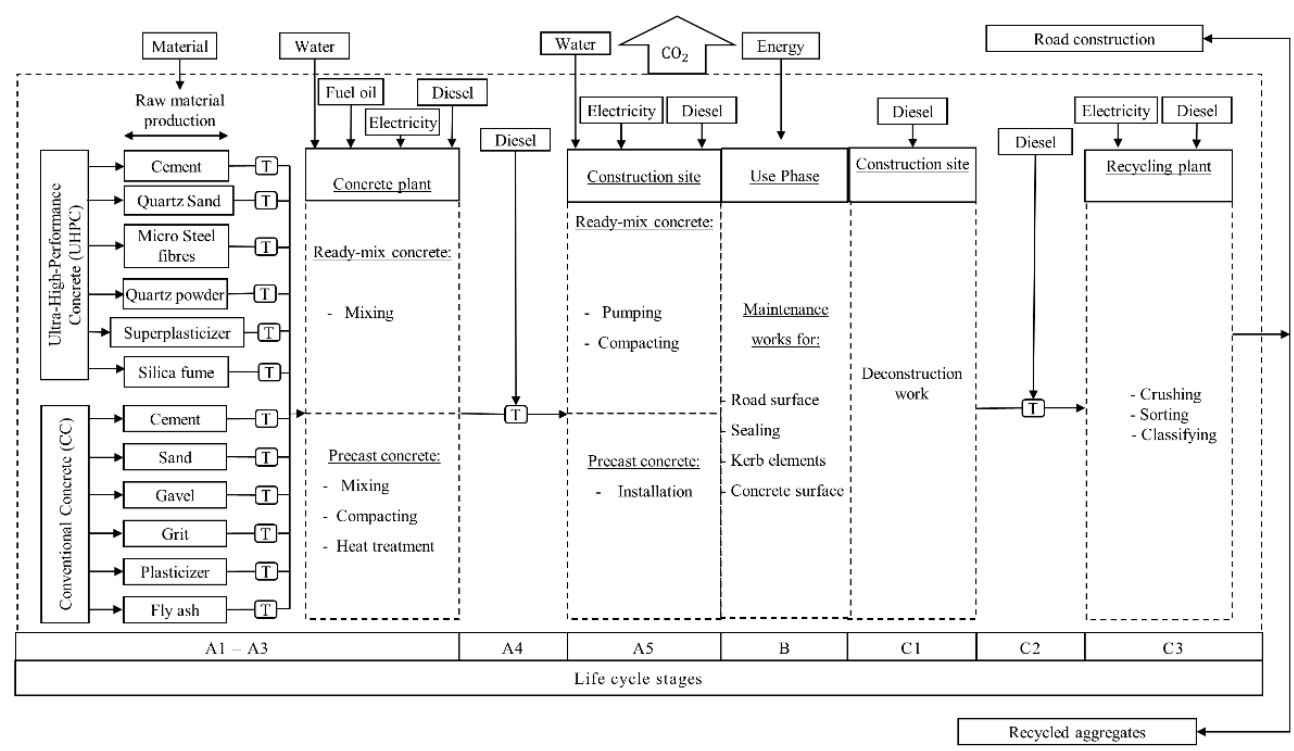

Figure 1. Diagram of life cycle assessment processes of cradle-to-grave of Ultra-High-Performance Concrete (UHPC) and Conventional Concrete (CC). Note: $\mathrm{T}=$ Transport. 


\subsubsection{Life Cycle Stages A1-A3}

A1 life cycle stage of the concrete represents cradle-to-grave inventory (A1-A3) of its ingredient, for instance, A1-A3 production process of cement. Cement production includes raw material extraction (A1), transport of the raw materials (A2), and production process (A3), e.g., manufacturing of clinker, and cement grinding. Production process of quartz sand and quartz powder is defined within GaBi XIV construction materials [43]. This process includes grinding into smaller particle size and separation from impurities. Superplasticizers are defined according to the environmental product declaration (EPD) of the German Association Deutsche Bauchemie [46]. Production process of steel fibers is exemplified by Stengel and Schießl [47]. The process chain includes crude steel production, hot rolling to wire, descaling, dry drawing, wet drawing, annealing, twisting, and cutting to length.

A2 life cycle stage represents the transport of concrete ingredients to the concrete plant. Transporting types and distances of cement, aggregate, fly ash, plasticizers are taken from an LCA study conducted by the German ready-mixed concrete association [48], while interviews are undertaken with experts from stakeholder for getting transporting information of quartz sand, quartz powder, silica fume and steel fibers. Types of transport and distances are shown in Table 2.

Table 2. Transportation types and distances of concrete ingredients.

\begin{tabular}{cccccc}
\hline \multirow{2}{*}{ Material } & \multirow{2}{*}{$\begin{array}{c}\text { Transport } \\
\text { Distance }(\mathbf{k m})\end{array}$} & \multicolumn{3}{c}{ Type of Transport } & \multirow{2}{*}{ Reference } \\
\cline { 3 - 5 } & & Truck \% & Train \% & Ship \% & \\
\hline Sand; Gravel; Grit & 39 & 88 & 1.90 & 10.10 & {$[45]$} \\
Cement & 106 & 79.90 & 8.90 & 11.20 & {$[45]$} \\
Fly ash & 100 & 100 & - & - & {$[45]$} \\
Plasticizers & 100 & 100 & - & - & {$[45]$} \\
Quartz sand; Quartz & 150 & 100 & - & - & Interviews \\
powder & 700 & 100 & - & - & Interviews \\
Silica fume & 230 & 100 & - & - & Interviews \\
Steel fibers & & & &
\end{tabular}

A3 life cycle stage comprises the concrete mixing process. Concerning CC, life cycle inventories of electricity, diesel and fuel oil demand are analyzed according to data from a technical report of energetic optimization of concrete production of the ready-mix concrete plant done at the University of Stuttgart [49]. The electricity, diesel and fuel oil demand are determined by averaging the energy demand of three concrete plants that were analyzed in in Reference [49]. It contains, in addition to the single mixing process, the whole needs of the concrete plant, for instance, lighting and laboratory operation requirements. The energy demand to produce UHPC has to be calculated according to the longer mixing process of 10-15 $\mathrm{min}$ [19]. The ready-mix concrete is compacted at the construction site, which refers to A5 life cycle stage.

In addition, A3 life cycle stage of precast concrete includes compacting and heating treatment of the concrete. The research project of the Technical University of Cottbus [50] describes the electricity demand of two high-frequency internal vibrators by considering a power of $1.5 \mathrm{~kW}$ and a compacting period of five minutes per cubic meter with a utilization rate of $100 \%$; the electricity demand is $0.25 \mathrm{kWh} / \mathrm{m}^{3}$. The modeling of the heat treatment is based on the expert's interviews. Therefore, an amount of $3 \mathrm{~L} / \mathrm{m}^{3}$ of fuel oil is required. Table 3 shows the need for electricity, fuel oil and diesel for the A3 life cycle of the production of $1 \mathrm{~m}^{3}$ concrete. 
Table 3. Inventories of the required energy regarding A3 life cycle stage of the production of $1 \mathrm{~m}^{3}$ concrete.

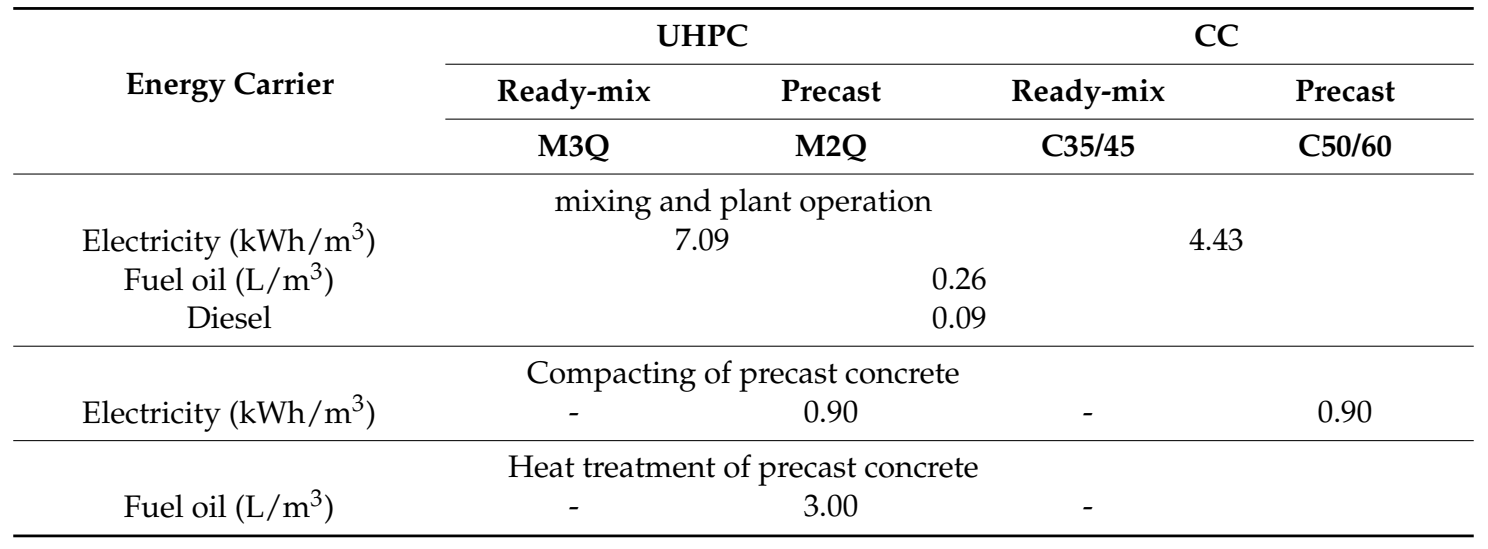

\subsubsection{Life Cycle Stages A4-A5}

LCI of the A4 life cycle stage of CC and UHPC are the same. The ready-mix concrete is transported by a truck mixer from the concrete plant to the construction site. The GaBi database [43] does not contain such a process. Therefore, the transport of the ready-mix concrete is modeled by using a conventional truck and adding an additional diesel input regarding the higher fuel consumption of a truck mixer. The average fuel consumption of a truck mixer is $0.48 \mathrm{~L} / \mathrm{km}$ [51]. The truck has a fuel consumption of $0.35 \mathrm{~L} / \mathrm{km}$ [43]. Consequently, additional input of $0.13 \mathrm{~L} / \mathrm{km}$ is added. Data of the average transport distance is based on the annual report in 2017 of the German Federation of the ready-mixed concrete [52], which is $16.3 \mathrm{~km}$ as the average transport distance for ready-mix concrete 2014-2016.

The transport of the precast concrete is modeled by using a truck with a total weight of $34-40 \mathrm{t}$ and a capacity of $27 \mathrm{t}$ with fuel consumption of $0.46 \mathrm{~L} / \mathrm{km}$ [43]. Environmental product declaration of structural concrete [40] defined an average distance of $180 \mathrm{~km}$ for the transporting of the precast concrete. The utilization rate of the trucks capacity was assumed to be $100 \%$ on the way to the construction site and $0 \%$ on the return which leads to an average rate of $50 \%$, life cycle stage, A5, includes installation at the construction site. Concrete truck pump and compactors are using for the installation of ready-mix concrete. The technical data are specified according to the research project of the Technical University of Cottbus [50]. Power of concrete truck pump is $231 \mathrm{~kW}$ and an output capacity of $164 \mathrm{~m}^{3} / \mathrm{h}$, with a utilization rate of $50 \%$. This is equivalent to an operating period of $0.012 \mathrm{~h} / \mathrm{m}^{3}$. Precast concrete is either installed by using a revolving tower crane or by using a mobile crane [40]. In terms of the considered case study (see Section 2.4), a mobile crane is selected with a maximum payload of $80 \mathrm{t}$ and a power of $320 \mathrm{~kW}$ [50].

\subsubsection{Life Cycle Stages C1-C3}

C1 life cycle stage of UHPC and CC refers to the deconstruction measures. They differ from each other in the type, the capacity, and the fuel consumption of excavator. CC could be demolished using an excavator with a total weight of $30 \mathrm{t}$ and fuel consumption of $18 \mathrm{~L} / \mathrm{h}$ [50]. The capacity of the machine is assumed to be $30 \mathrm{~m}^{3} / \mathrm{h}$ according to the recommendations from experts. In terms of UHPC, there is no documented practical experience concerning the demolishing process [14]. A more powerful machine and a longer deconstruction period are recommended by the experts; therefore, the diesel input is determined of an excavator with a total weight of $50 \mathrm{t}$, fuel consumption of $35 \mathrm{~L} / \mathrm{h}$ and a capacity of $5 \mathrm{~m}^{3} / \mathrm{h}$.

Transport to the recycling plant represents C2 life cycle stage. In Germany, the construction waste is usually transported by trucks with a total weight of $40 \mathrm{t}$ [53]. The distance to the recycling plant is $30 \mathrm{~km}$ [50]. The utilization rate of the trucks is assumed to be $50 \%$. 
Life cycle stage of C3 includes the treatment of the construction waste. The waste of CC is going to be pre-crushed with an excavator and transported to the processing plant by a wheel loader, related technical specifications are described by Heyn and Mettke [50]. In case of UHPC, the same specifications of the wheel loader could be considered. For the pre-crushing using the excavator, the experts recommended that an additional utilization rate of $20 \%$ should be considered in comparison with the treatment of CC. Related LCI processes are described within the SI 4.

\subsection{Footprint Categories}

\subsubsection{Carbon Footprint}

The Joint Research Center (JRC) of the European Commission recommends using characterization factors $(\mathrm{CFs})$ of a 100-year time horizon global warming potential $\left(\mathrm{GWP}_{100}\right)$ for defining the carbon footprint [54]. The carbon footprint refers to the GHG emission accompanied within the life cycle process chain of a product quantified in $\mathrm{kg} \mathrm{CO}_{2}$ equivalents. $\mathrm{CFs}$ are documented in the fifth assessment report (AR5) by the Intergovernmental Panel on Climate Change (IPCC) [55]. The elementary flows are set up to be comparable with GaBi construction material database in openLCA software [5].

\subsubsection{Material Footprint}

Material footprint is defined in terms of Raw Material Input (RMI) and Total Material Requirement (TMR). RMI measures cumulative raw materials used within the whole process chain of a product $[26,56]$. Used and unused extractions could be determined by TMR. The unused extraction refers to all material that is taken from the environment to enable the extraction of the primary raw material [57].

The TMR thus measures the total amount of abiotic and biotic primary material required over the complete life cycle $[21,58]$. Regarding construction materials, RMI and TMR address all materials input from the environment during production, transport, use, maintenance, demolishing, and recycling [5].

CFs of RMI are developed by the Sustainable Resource Futures (SURF) group in the Center for Environmental Systems Research (CESR) at the University of Kassel [57,59,60], whereas the background methodology is well described and is applied for the assessment of the resource use of the building's exterior walls [5]. TMR measures the total of the RMI plus unused extractions [58]. Data on unused extractions is documented by WU [61].

\subsubsection{Water Footprint}

Water footprint is assessed according to the AWARE method [27], which is the current WULCA (Water Use in LCA) consensus LCA method for water scarcity in compliance with ISO 14046 [62]. Considering hydrological water availability, human water consumption and needs of aquatic freshwater ecosystem, impacts of water use are expressed in terms of the indicator available water remaining per water shed and country.

AWARE aims at identifying the risk of freshwater depletion for any other water user in the same area. The resulting indicator Availability-Minus-Demand with the unit $\mathrm{m}^{3} / \mathrm{m}^{2} *$ month of any basin is related to the world average to calculate regionalized CFs, which are available online http:/ / www.wulca-waterlca.org/aware.html.

The CFs represent "a relative value of the impact score of water consumption" [27], (p. 374) in comparison with the world average consumed in a basin. CFs are ranged from 0.1 to $100 \mathrm{~m}^{3}$ world $\mathrm{eq} / \mathrm{m}^{3}$. For instance, the German CF of 1.36 [27] indicates that in Germany 1.36 times less water is remaining in a specific period than in the world average, whereas the world average $\mathrm{CF}$ is equal to 42.95 [27]. Regions with less than one percent of the world average available water remaining are automatically set to the maximum value of 100 , thus being marked as extreme arid areas.

Water consumption in different regions is comparable due to considering the units $\mathrm{m}^{2} \cdot \mathrm{month}$ equivalent in every basin: Consuming water in two regions with the same available water remaining 
per $\mathrm{m}^{2}$. month is therefore assumed to be equal. Concerning the LCA calculations related to Section 3 of this article, both products are produced in Germany, therefore water consumption is weighted using German AWARE CFs. For the purpose of transferring the methodology to processes not located in Germany, the CFs must be adapted accordingly.

\subsection{Case Study Description}

Two design options of an overpass road bridge in Germany (Obertiefenbach Bridge) are tested $[63,64]$. The first design option implied the exclusive use of CC (CC-Design) and the second one is a combination of CC and UHPC (UHPC Design). The bridge should provide a shorter time of construction and high performance in terms of durability, resistance to the mechanical loads, and stiffness. Therefore, UHPC is suggested to enhance the design of the bridge. UHPC was proposed to substitute use of the CC in the top layer of the deck slab, hinge over the middle piers, and the kerb. All the other elements of the bridge, e.g., main girders, abutments, and middle piers are designed to be built using CC. Construction materials are shown in Table 4. For more information regarding drawings and material specifications, see Brühwiler et al. [63] and Schmidt et al. [64].

Table 4. Construction materials of the two design options of the bridge.

\begin{tabular}{|c|c|c|c|c|}
\hline Bridge Structure Element & UHPC Design & Quantity & CC-Design & Quantity \\
\hline Abutments and middle & $\mathrm{C} 35 / 45$ & $25.00 \mathrm{~m}^{3}$ & C35/45 & $40.00 \mathrm{~m}^{3}$ \\
\hline support with 5 single piers & Reinforcing steel & $6.50 \mathrm{t}$ & Reinforcing steel & $27.00 \mathrm{t}$ \\
\hline $\begin{array}{l}\text { Support over the } 5 \text { middle } \\
\text { single piers }\end{array}$ & $\begin{array}{c}\text { Concrete hinges with UHPC cast } \\
\text { on site (M2Q) }\end{array}$ & $1.10 \mathrm{~m}^{3}$ & - & - \\
\hline \multirow{4}{*}{ Main girders (longitudinal) } & Precast concrete $\mathrm{C} 50 / 60$ & $180.00 \mathrm{~m}^{3}$ & $\begin{array}{c}\text { Precast concrete } \\
\text { C50/60 }\end{array}$ & $142.00 \mathrm{~m}^{3}$ \\
\hline & Reinforcing + Prestressing steel & $54.80 \mathrm{t}$ & \multirow{3}{*}{$\begin{array}{c}\text { Reinforcing }+ \\
\text { Prestressing steel } \\
\text { C35/45 } \\
-\end{array}$} & $33.00 \mathrm{t}$ \\
\hline & Polyurethane putty & $0.12 \mathrm{t}$ & & $119.00 \mathrm{~m}^{3}$ \\
\hline & M3Q & $7.00 \mathrm{~m}^{3}$ & & - \\
\hline \multirow{3}{*}{ Sealing } & M3Q & $20.50 \mathrm{~m}^{3}$ & \multirow{3}{*}{$\begin{array}{c}\text { Epoxy resin } \\
\text { Quartz sand } \\
\text { Bitumen sheets }\end{array}$} & $0.56 \mathrm{t}$ \\
\hline & - & - & & $0.84 \mathrm{t}$ \\
\hline & - & - & & $3.09 \mathrm{t}$ \\
\hline \multirow{4}{*}{ Road surface } & Poured asphalt & $1.73 \mathrm{t}$ & \multirow{4}{*}{$\begin{array}{c}\text { Poured asphalt } \\
- \\
\text { Jointing material } \\
\text { Aggregates }(2 / 5), \\
(5 / 8)\end{array}$} & $56.45 \mathrm{t}$ \\
\hline & Stone mastic asphalt (SMA) & $28.80 \mathrm{t}$ & & - \\
\hline & Jointing material & $0.09 \mathrm{t}$ & & $0.16 \mathrm{t}$ \\
\hline & High-grade chippings $(0 / 5)$ & $0.90 \mathrm{t}$ & & $1.95 \mathrm{t}$ \\
\hline \multirow{2}{*}{ Kerb elements } & Epoxy resin & $1.24 \mathrm{t}$ & \multirow{2}{*}{$\begin{array}{c}- \\
\text { Ready-mix } \\
\text { concrete C25/30 }\end{array}$} & - \\
\hline & M2Q & $33.00 \mathrm{~m}^{3}$ & & $59.00 \mathrm{~m}^{3}$ \\
\hline
\end{tabular}

However, the design of the bridge is wholly described by Brühwiler et al. [63]. An overview of UHPC Design will be shortly discussed. The bridge consists of two-span, $22.5 \mathrm{~m}$ and $21.5 \mathrm{~m}$, with main five girders supported by the abutments and one middle support. The middle support consists of five single piers to support the five girders without a cross girder to provide efficiency in lighting. The main girders are precast, prestress, and longitudinally pretension reinforced concrete. When the main girders are installed on the abutments from the ends and piers from the middle, in the long direction, the space between them in the middle is filled out with UHPC. Then a layer of UHPC $(3 \mathrm{~cm})$ is cast on the top surface of the deck slab for the connection of the girders and waterproofing protection. Kerbs are prefabricated from UHPC, then glued on the top surface of the bridge.

The system boundaries include the whole life cycle from the raw material extraction to the end-of-life phase of the bridge within the two design options. LCA calculations are done within the $\mathrm{GaBi}$ database. Regarding materials, which are not available in the GaBi database, i.e., steel fibers, they are modeled within the ecoinvent database [45]. For the sealing layer, a standard bituminous sheeting with a polyester fleece bearing is used. Below the kerb elements, a glass fleece bituminous sheeting is applied. LCA modeling of A1-A3 is typical to Section 2.2.1. 
In terms of the module A4, for the transportation modeling, van, truck, and road train are used for the transportation modeling. The choices of the transport type depend on the amount of transported material. Transportation distances are defined according to Lünser [65]. An additional amount of diesel should be added to the transport process of the concrete regarding Section 2.2.2. During the transport of poured asphalt, the boiler needs an additional input of diesel and fuel oil. According to the expert interviews, the diesel demand of a boiler is $8 \mathrm{~L} / \mathrm{h}$ and the fuel demand is $3.5 \mathrm{~L} / \mathrm{h}$.

A5 represents the installation of precast and ready-mix concrete at the construction site. Diesel demand of the construction equipment and the amount of liquefied petroleum gas to install the bituminous asphalt sheeting are defined according to the expert's interviews.

The lifespan of the bridge, use phase B4, is assumed to be 90 years [65]. Maintenance works and lifespan of the structure elements bridge are modeled according to Lünser [65] as 20 years for the lifespan of the road surface and sealing, and 30 years for the lifespan of kerb elements and concrete surface. LCA calculations contain all expenditures for the removal and renewal (replacement) of construction materials including the transport to and from the construction site. A number of the replacements are shown in Table 5. Road surface and sealing must be renewed four times. Kerb elements and concrete surface must be renewed two times. The concrete surface refers to the part beneath the sealing layer which is often damaged by deicing salts. It is assumed that after 30 years $20 \%$ of the area would need to be renewed. In case of the UHPC Design, the sealing layer is not existent. Instead, it has a $3 \mathrm{~cm}$ thick UHPC layer which prevents a possible deicing attack due to a very high impermeability [66]. The high durability of UHPC facilitates a long lifetime and does not need to be renewed after 30 years. Nevertheless, it is assumed that the asphalt overlay would be renewed after 20 years. Furthermore, the UHPC kerb elements would not need to be removed after 30 years. The module B4 is divided into B4 (a): renewal of road surface and sealing and B4 (b): renewal of kerb elements and concrete surface.

Table 5. Frequency of replacements required for the maintenance work during use phase of the bridge.

\begin{tabular}{ccc}
\hline \multirow{2}{*}{ Element } & \multicolumn{2}{c}{ Renewal } \\
\cline { 2 - 3 } & UHPC Design (Number) & CC-Design (Number) \\
\hline Road surface & 4 & 4 \\
Sealing & - & 4 \\
Kerb elements & - & 2 \\
Concrete surface & - & 2 \\
\hline
\end{tabular}

For the deconstruction life cycle stage, $\mathrm{C} 1$, crowbar, excavator loader, hydraulic hammer, wheel loader, and cutters are assumed to be used; They require a diesel consumption of $17.6 \mathrm{~L} / \mathrm{m}^{3}$ in terms of CC [65]. To consider the higher performance of UHPC the fuel consumption is doubled resulting in $35.2 \mathrm{~L} / \mathrm{m}^{3}$ according to the experts' interviews. A milling machine with $2.54 \mathrm{~L} / \mathrm{m}^{3}$ diesel demand could be used for the deconstruction of the road surface, and the deconstruction of the sealing could be done using an excavator with $0.20 \mathrm{~L} / \mathrm{m}^{2}$ diesel demand and $0.13 \mathrm{~L} / \mathrm{m}^{2}$ liquefied petroleum gas demand [65]. The construction waste is sorted by material and transported, C2 life cycle stage. The transportation is assumed to be done by truck ( $27 \mathrm{t}$ payload) over a distance of $30 \mathrm{~km}$ ) to the recycling plant [50]. Life cycle stage of $\mathrm{C} 3$ represents treatment of the construction waste. LCA is modeled for the needed wheel loader, excavator, and other processes in relation to waste plant. In terms of CC, the processes needed are a wheel loader with $0.60 \mathrm{~L} / \mathrm{m}^{3}$ diesel demand, excavator with $0.30 \mathrm{~L} / \mathrm{m}^{3}$ electricity demand of $18.26 \mathrm{~L} / \mathrm{m}^{3}$ for other processes within a waste plant [65]. Regarding UHPC, however, the same demand of diesel of the wheel loader is needed, and an additional diesel demand of excavator is needed, i.e., $0.43 \mathrm{~L} / \mathrm{m}^{3}$ and simultaneously $21.21 \mathrm{MJ} / \mathrm{t}$ of electricity is needed for other processes within the waste plant. 


\subsection{Definition of The Functional Unit}

ISO 14040 [67] defined the functional unit of a product system as a measure of the benefit of the functional outputs. However, the environmental footprints of the UHPC in comparison with CC should be provided within the functionality of the final products, e.g., bridges, because UHPC could strongly reduce mass to load-bearing capacity. LCA results for $1 \mathrm{~m}^{3}$ of UHPC in comparison with CC will be discussed in Sections 3.1 and 3.2 in order to enhance future studies with other applications. The results related to a practical application of UHPC will be shown within the Section 3.3. When analyzing and comparing the life cycle of bridges, a functional unit should represent an equal practical value [65]. LCA results are done for the two design variants of the bridge. The practical value (functional unit) is defined as the whole bridge because two design options are connecting two identical places, assigned to the same bridge class, and having the same load capacity and length.

\section{Results and Discussion}

\subsection{Construction Materials Level}

\subsubsection{Carbon Footprint at Construction Materials Level}

LCA results of the carbon footprint of $1 \mathrm{~m}^{3}$ of UHPC in comparison with $1 \mathrm{~m}^{3}$ of CC are shown in Figure 2. The results show a higher quantity of GHG of UHPC. A1-A3 life cycle stages contribute to more than $90 \%$ of the carbon footprint of all the considered mixtures of concrete. Therefore, the share contributions of the materials within A1-A3 are additionally discussed. Regarding UHPC, GHG emissions of the production of the steel fibers are contributing to more than $40 \%$ of the carbon footprint of M3Q and M2Q. Cement production is responsible for more than $80 \%$ of the GHG emissions of the considered mixtures of CC, C35/C45 and C50/60.

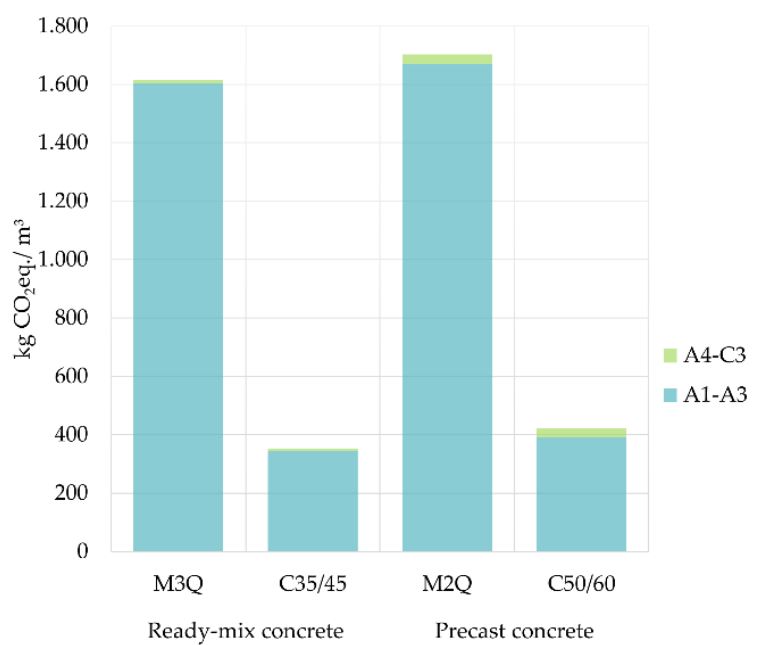

(a) A1-C3 life cycle stages

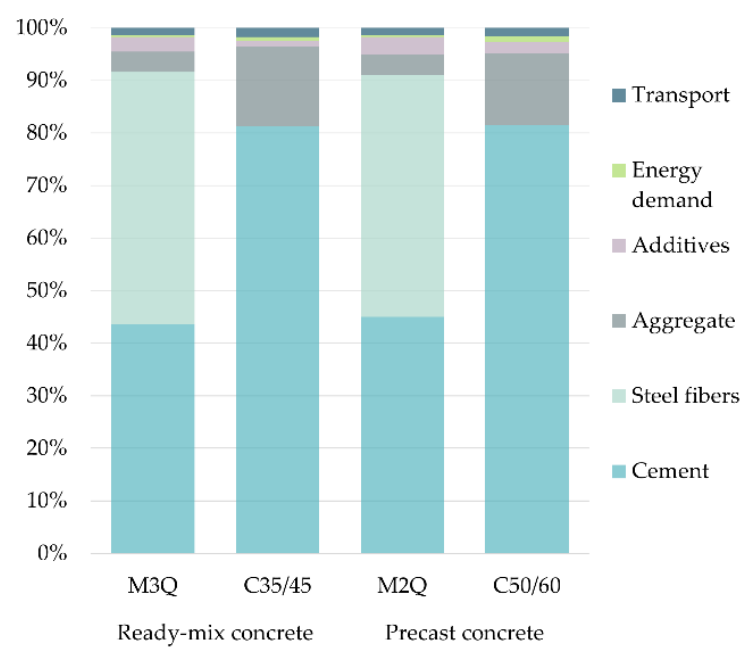

(b) A1-A3 life cycle stages

Figure 2. (a) Carbon Footprint of Ultra-High-Performance Concrete (M3Q and M2Q) in comparison with conventional concrete (C35/45 and $\mathrm{C} 50 / 60)$ per $\mathrm{m}^{3}$; (b) Share of materials of the carbon footprint for the A1-A3 life cycle stages.

\subsubsection{Material Footprint at Construction Materials Level}

LCA results of the material footprint (measured in RMI and TMR) are shown in Figure 3. The material footprint of UHPC is much higher than that one of the CC. Figure 3 reveals that there has been a marked increase in the values of TMR of UHPC mixtures, i.e., M3Q and M2Q, owing to high value of unused per used extractions of the production of the steel fibers. In terms of life cycle stages A1-A3 of the CC (C35/45 and C50/60), material footprint is mainly dominated by more than 
$65 \%$ from the production process of aggregate and by more than $30 \%$ from the production process of cement.

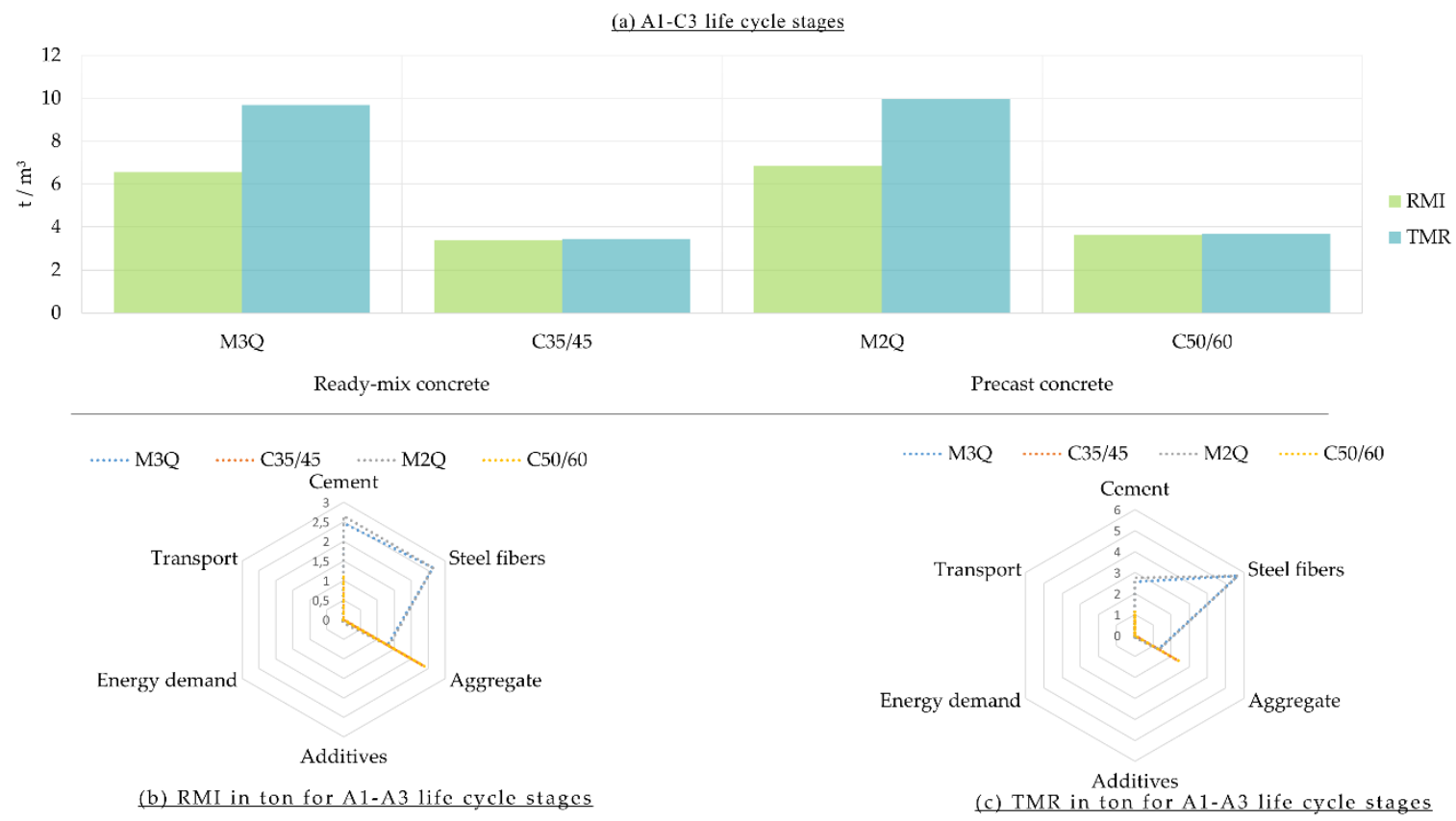

Figure 3. (a) Material Footprint of Ultra-High-Performance Concrete ( $M 3 Q$ and $M 2 Q)$ in comparison with CC (C35/45 and C50/60) per $\mathrm{m}^{3}$; (b) Share of materials of the Raw Material Input (RMI) for the A1-A3 life cycle stages; (c) Share of materials of the Total Material Requirement (TMR) for the A1-A3 life cycle stages.

\subsubsection{Water Footprint at Construction Materials Level}

Figure 4 shows that the water footprint is three times increased when UHPC is used. The largest volume of water is consumed by the $\mathrm{M} 2 \mathrm{Q}$ mixture of concrete. A1-A3 life cycle stages are majorly responsible for the water footprint in comparison with other life cycle stages. The production process of cement dominates the water footprint. Due to the higher cement content in the ultra-high-strength concretes, its water footprint is correspondingly high.

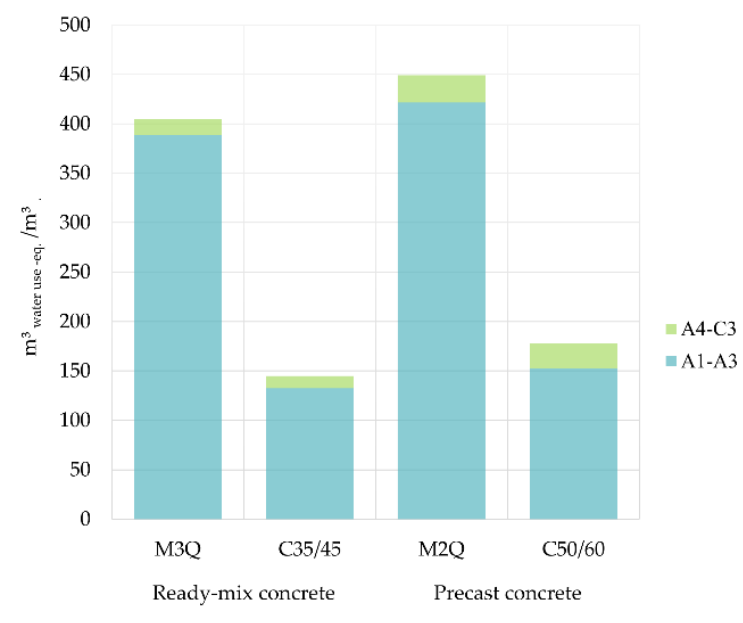

(a) A1-C3 life cycle stages

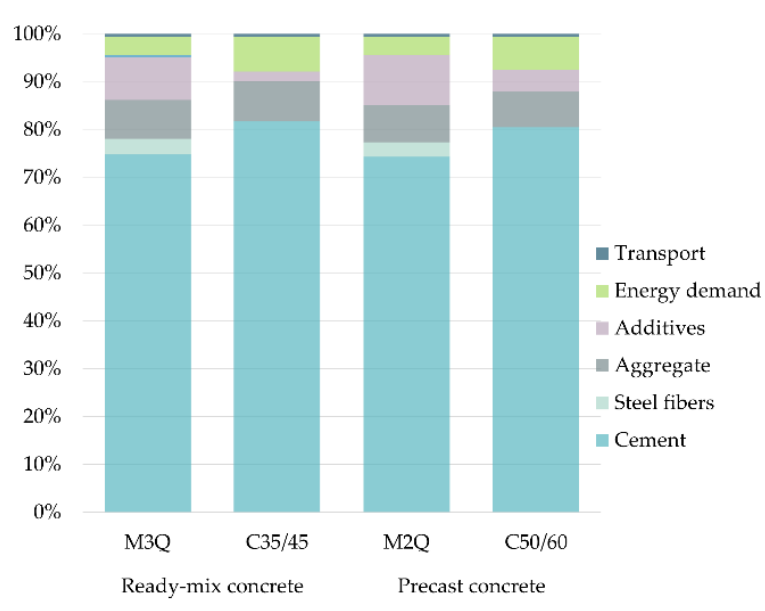

(b) A1-A3 life cycle stages

Figure 4. (a) Water footprint of Ultra-High-Performance Concrete (M3Q and M2Q) in comparison with conventional concrete $(\mathrm{C} 35 / 45$ and $\mathrm{C} 50 / 60)$ per $\mathrm{m}^{3}$; (b) Share of materials of the water footprint for the A1-A3 life cycle stages. 


\subsection{Sensitivity Analysis at The Construction Materials Level}

The evaluation of the considered footprints shows that the UHPC (M2Q) has the highest environmental impact. The analysis results of UHPC ready-mix concrete (M3Q) show slightly lower environmental impacts but they are still higher than $\mathrm{CC}$ results. About CC, the concrete of compressive strength class $\mathrm{C} 50 / 60$ has more environmental impact. Furthermore, as a commonality of the three footprints can be seen that the highest environmental impact occurs in the production stage A1-A3. These contributed to more than $95 \%$ to the material footprint and $90 \%$ to the carbon and water footprint. Dominant processes of the carbon and water footprint are the production of cement and steel fibers, as well as the aggregates of the material footprint. The micro steel fibers have been also identified for the largest unused per used extractions.

The sensitivity analysis will examine how the footprints are sensitive to changing the two dominants variants as follows:

- $\quad$ Type of cement.

- Production process of micro steel fibers.

\subsubsection{Type of Cement}

The CEM I 52.5 R-HS/NA is used as the type of cement for the UHPC [14]. This is a fast hardening Portland cement with a high sulfate resistance (HS) and a low alkali content (NA). The Portland cement CEM I has high clinker content of 95-100\% according to EN 197-1 [41]. High clinker content of the cement increases the accompanied GHG emissions, whereas, cement types CEM II-CEM V have a lower clinker content. The UHPC practice applications listed in the literature have been mostly performed with C3A lean Portland cement. However, in the Netherlands, a bridge of UHPC was built with a CEM III 52.5 [68]. According to EN 197-1 [41], the type of cement CEM III/A has a clinker content of 35-64\%. The sensitivity analysis will include using of cement type CEM III/A as a binder for all mixtures of concrete as shown in Table 6.

Table 6. Types of cement of the considered mixtures of concrete in terms of results of the sensitivity analysis.

\begin{tabular}{ccccc}
\hline \multicolumn{2}{c}{ Type of Concrete } & Quantity $\mathbf{( k g / \mathbf { m } ^ { 3 } )}$ & Ex-Ante Type of Cement & Replaced by \\
\hline \multirow{2}{*}{ Ready-mix concrete } & UHPC M3Q & 775 & CEM I 52.5 & \\
\multirow{5}{*}{ Precast concrete } & C35/45 & 356 & CEM II / A & CEM III/A \\
& UHPC M2Q & 832 & CEM I 52.5 & \\
\hline
\end{tabular}

\subsubsection{Production Process of Steel Fibers}

The main part of steel production for instance in Germany takes place in the blast furnace route [69]. Pig iron is made in the blast furnace route using coke; consequently, the iron is then converted to steel in the basic oxygen furnace. $20-30 \%$ of scrap is used within blast furnace route, whereas more than $42 \%$ of scrap is used within the production of steel in an electric arc furnace with less energy use [69]. Therefore, the sensitivity to the environmental impacts of changing the type of the production of the steel fibers of UHPC will be examined.

\subsubsection{Results of The Sensitivity Analysis}

Sensitivity of the footprints to the changing type of cement for all mixtures of UHPC and CC and type of production process of steel fibers for UHPC mixture will be shown in this section. Figure 5 shows that $42 \%$ of the carbon footprint of the UHPC mixtures is decreased. Potential saving of more than $30 \%$ of the carbon footprint of CC is accordingly presented. 


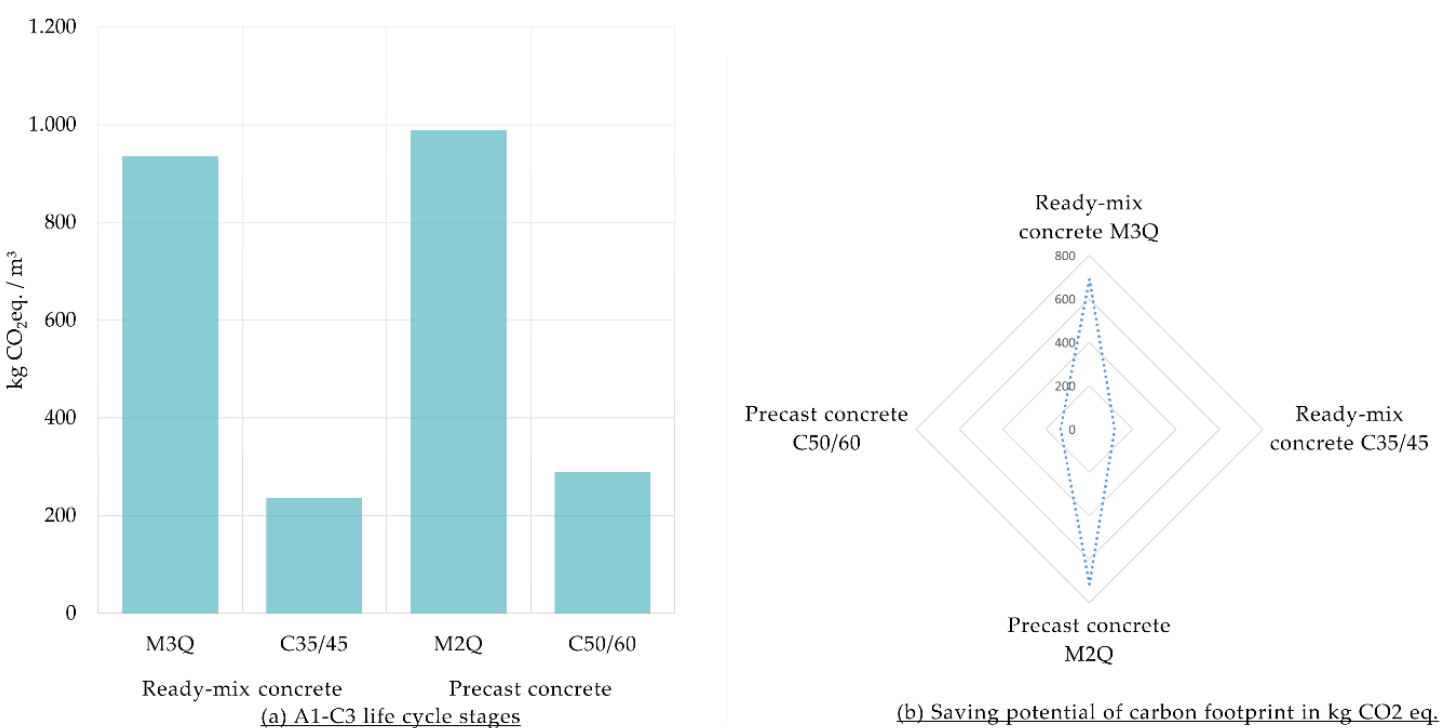

Figure 5. (a) Carbon Footprint of the Ultra-High-Performance Concrete (M3Q and M2Q) in comparison with conventional concrete (C35/45 and C50/60) regarding sensitivity analysis per $\mathrm{m}^{3}$; (b) Potential savings of carbon footprint in $\mathrm{kg} \mathrm{CO}_{2}$ equivalents regarding sensitivity analysis.

Regarding material footprint, the sensitivity analysis indicates that a potential saving of $62 \%$ could be done within the UHPC mixtures as shown in Figure 6 . This is mainly a sequence of using a high amount of secondary materials. TMR of CC is decreased by up to $17 \%$.
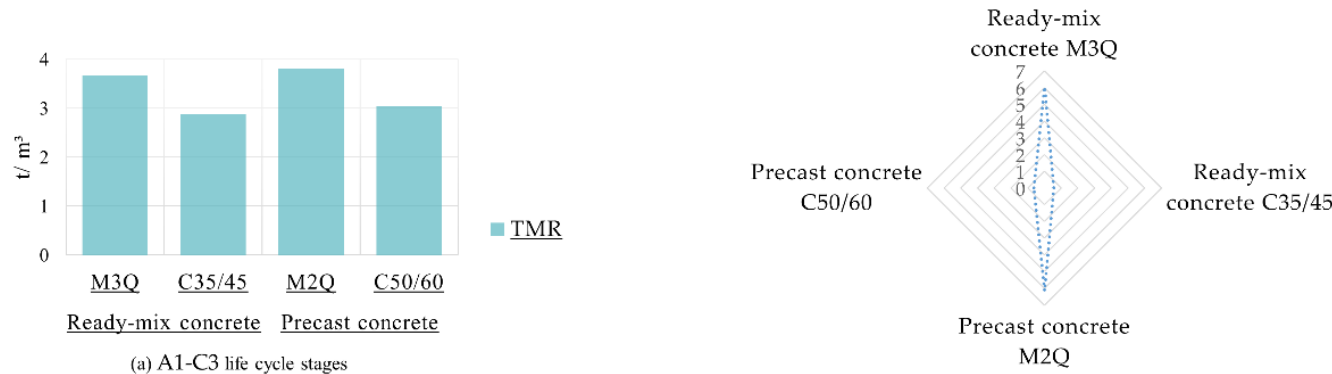

(b) Saving potential of TMR in $t / \mathrm{m}^{3}$

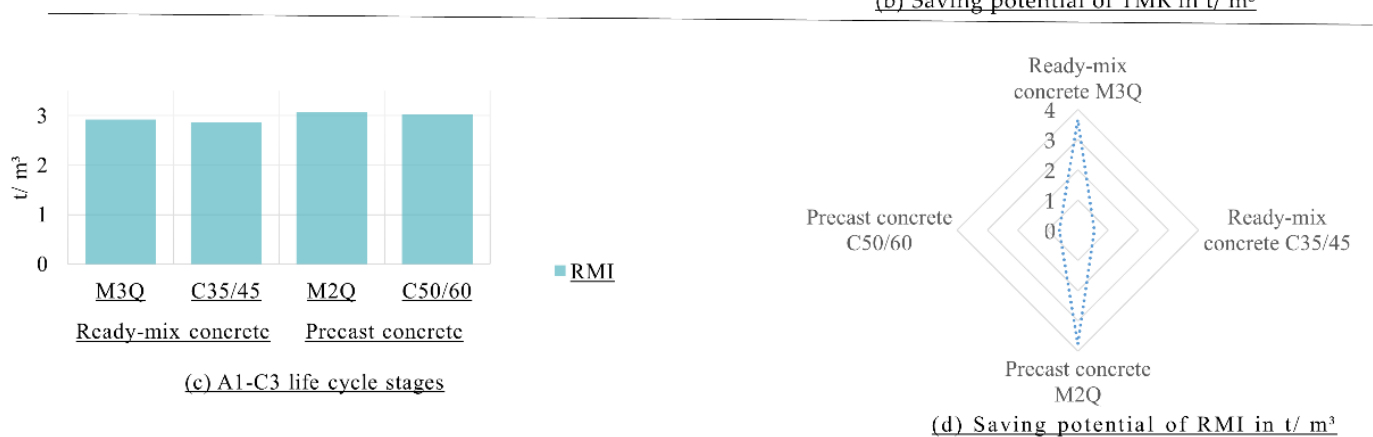

Figure 6. (a) Material Footprint in terms of TMR of the Ultra-High-Performance Concrete (M3Q and $\mathrm{M} 2 \mathrm{Q})$ in comparison with conventional concrete (C35/45 and C50/60) regarding sensitivity analysis; (b) Potential savings of TMR in ton regarding sensitivity analysis; (c) Material Footprint in terms of RMI of the Ultra-High-Performance Concrete (M3Q and $\mathrm{M} 2 \mathrm{Q}$ ) in comparison with conventional concrete (C35/45 and C50/60) regarding sensitivity analysis; (d) Potential savings of RMI in ton regarding sensitivity analysis.

Figure 7 shows that the water footprint could be slightly affected in comparison to other considered footprints. Using CEM III 52.5 as the type of cement for all mixtures of concrete and 
an electric arc furnace for steel fibers production could provide up to $17 \%$ less water footprint of UHPC mixtures and approximately $3 \%$ less water footprint of CC mixtures.

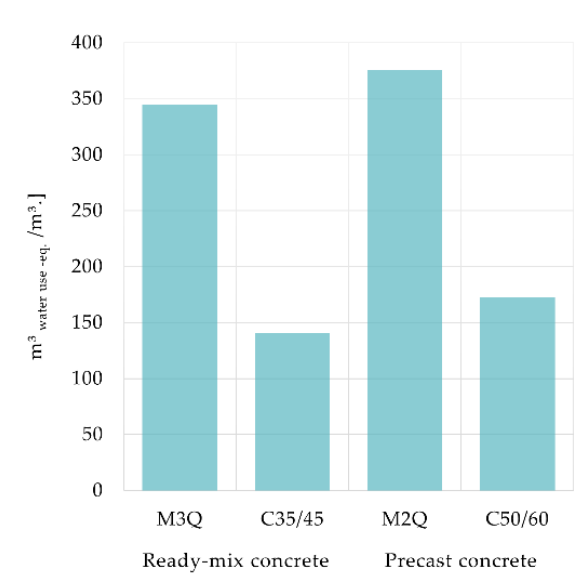

(a) A1-C3 life cycle stages

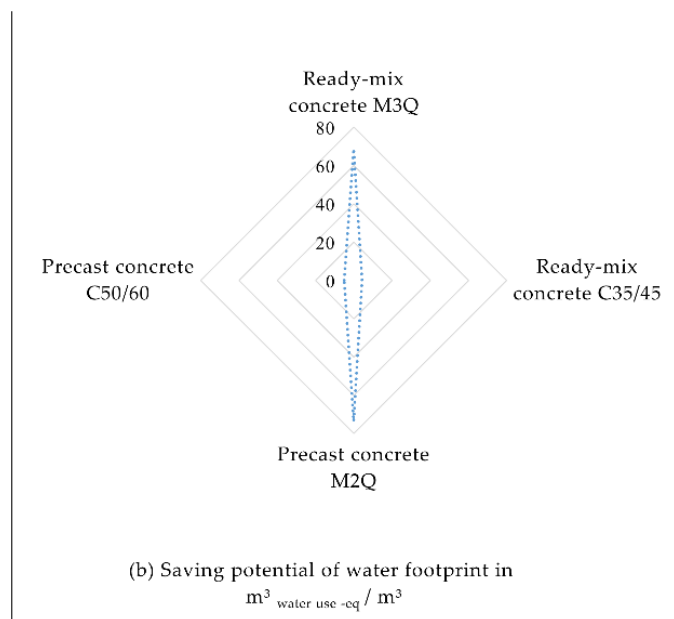

Figure 7. (a) Water Footprint of the Ultra-High-Performance Concrete (M3Q and M2Q) in comparison with conventional concrete (C35/45 and C50/60) regarding sensitivity analysis; (b) Potential savings of water footprint in $\mathrm{m}^{3}$ water use eq. per $\mathrm{m}^{3}$ regarding sensitivity analysis.

\subsection{Case Study Level}

\subsubsection{Carbon Footprint at Case Study Level}

The carbon footprint of the bridge with CC (CC-Design) could be decreased by about $40+\mathrm{CO}_{2}$ eq. when the UHPC is considered to enhance the design of the bridge (UHPC Design) as shown in Figure 8 . In terms of CC-Design, $63 \%$ of the carbon footprint comes from A1-A3 life cycle stages, whereas those stages contribute to $92 \%$ of the carbon footprint of the bridge when the UHPC is used. Analysis of A1-A3 stages shows that production processes of CC and steel mainly contribute to the carbon footprint of the CC-Design. On the other hand, production processes of UHPC, CC, and steel dominate GHG emissions of the bridge when UHPC is used altogether with CC (UHPC Design).
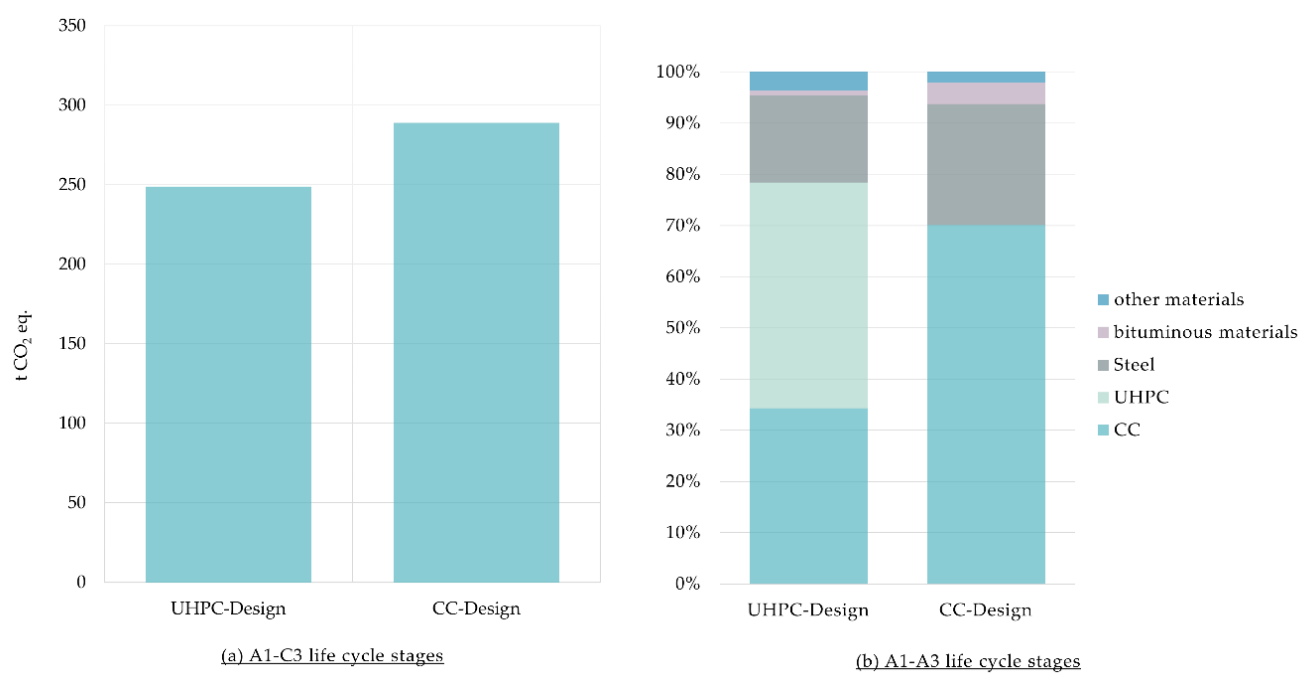

Figure 8. (a) Carbon footprint of the two designs of the bridge, Conventional Concrete Design (CC-Design) and Conventional Concrete enhanced with Ultra-High-Performance Concrete (UHPCDesign); (b) Share of materials of the carbon footprint for the A1-A3 life cycle stages. 


\subsubsection{Material Footprint at Case Study Level}

Figure 9 shows that a smaller material footprint could be seen when the UHPC Design is considered with a potential saving of more than $8 \mathrm{t}$ of the cumulative raw material used (RMI) and more than $6.5 \mathrm{t}$ in terms of TMR. CC and steel production processes contribute to $80 \%$ and $13 \%$ respectively to the material footprint of CC-Design. In terms of UHPC Design, CC has also the highest impact on the material footprint with $47 \%$, then comes the UHPC with $38 \%$.
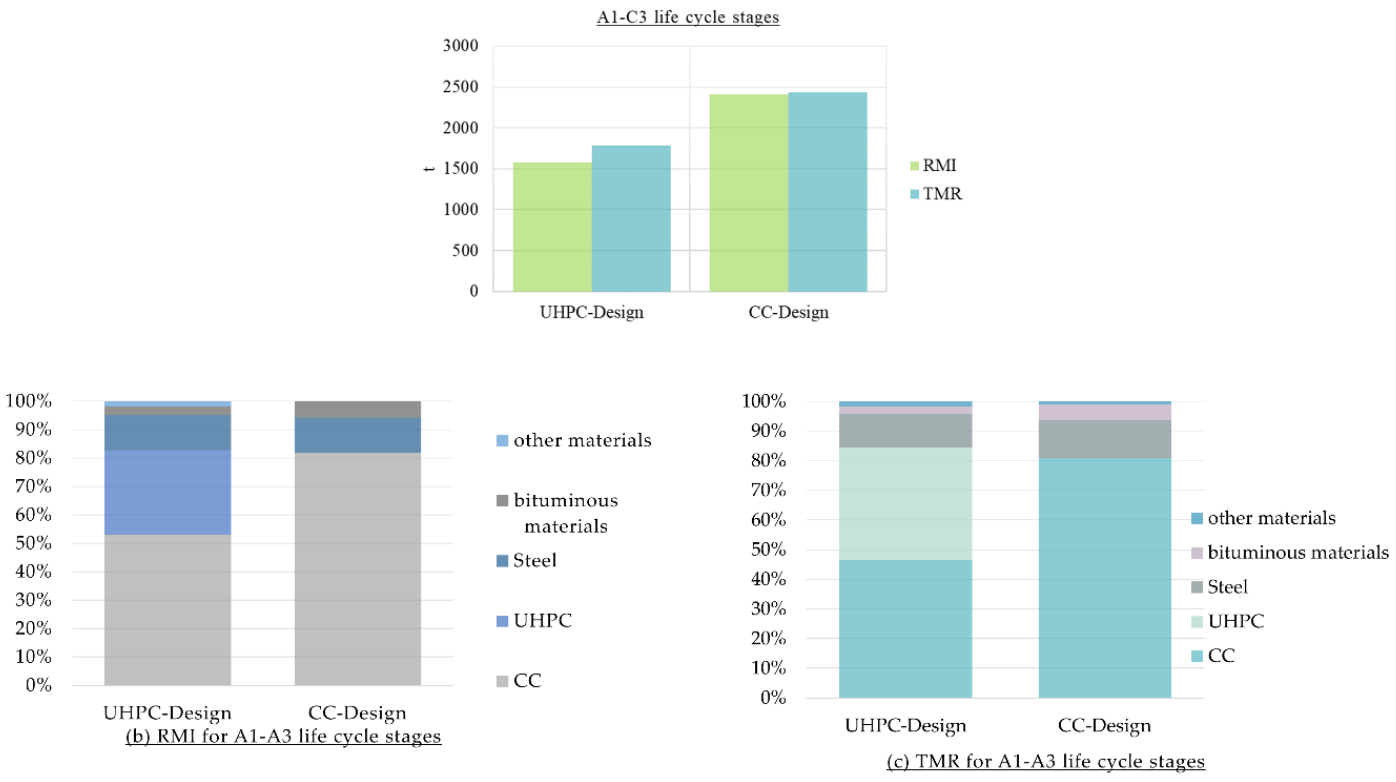

Figure 9. (a) Material footprint of the two designs of the bridge, Conventional Concrete Design (CC-Design) and Conventional Concrete enhanced with Ultra-High-Performance Concrete (UHPC-Design); (b) Share of materials of the RMI for the A1-A3 life cycle stages; (c) Share of materials of the TMR for the A1-A3 life cycle stages.

\subsection{Water Footprint at Case Study Level}

Water footprint could be reduced by more than $30 \%$ when the UHPC design is considered, as shown in Figure 10. Regarding the two design options of the bridge, production process of the steel is mainly responsible for the water footprint of $64 \%$ for the CC design and $59 \%$ for the UHPC design.

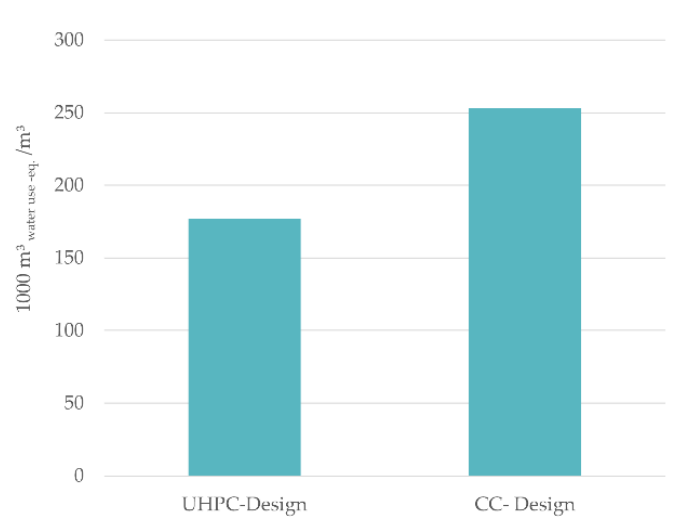

(a) A1-C3 life cycle stages

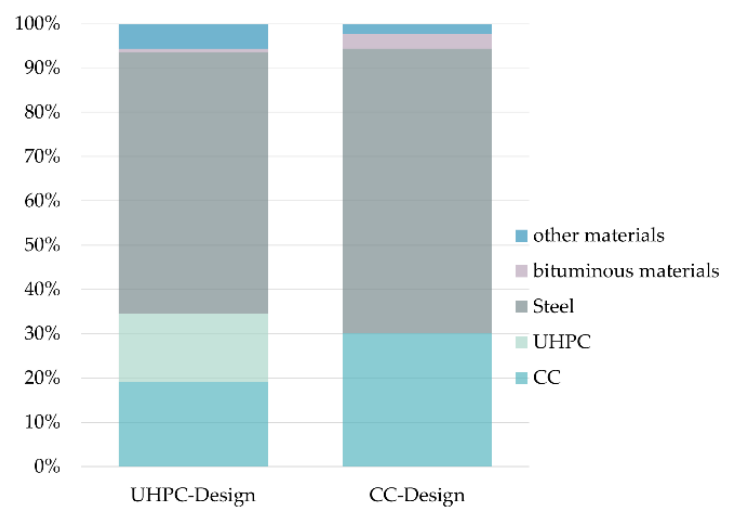

(b) A1-A3 life cycle stages

Figure 10. (a) Water footprint of the two designs of the bridge, Conventional Concrete Design (CC-Design) and Conventional Concrete enhanced with Ultra-High-Performance Concrete (UHPC-Design); (b) Share of materials of the water footprint for the A1-A3 life cycle stages. 


\subsection{Summary of Analyses at Material and Case Study Level}

In order to assess the impact of using UHPC, comparisons on material level are not sufficient. Hence, the functional unit should be considered at the case study level. Therefore, the environmental footprints of the UHPC is tested in comparison with CC on a practical application (design of an overpass road bridge). In contrast to the results for the environmental footprint of $1 \mathrm{~m}^{3}$ of concrete mixtures (Sections 3.1 and 3.2), the analysis results of the bridge design show that the design enhanced with UHPC (UHPC Design) could provide better environmental performance in terms of carbon, material, and water footprint. Results show that the environmental footprint is dominated by the A1-A3 life cycle stage. Therefore, those stages are analyzed more closely.

\section{Conclusions}

This article provides a comprehensive LCA of carbon, material, and water footprint of UHPC in comparison with CC using precast and ready-mix concrete. The GaBi construction materials database is used altogether with openLCA software, which enhances significantly quantifying environmental footprints of constructions. Results are analyzed at the construction material level to enhance sustainability aspects within design of constructions. Higher environmental impact of UHPC is shown when only the quantitative aspects are considered for the formulation of the functional unit. At the case study level, results are analyzed to test the footprints of UHPC in relation to the functionality provided. Better environmental performance of UHPC could be indicated within the assessment of a practical application such as a bridge. Cumulative raw material demand in terms of RMI and total primary material extraction in terms of TMR, in addition to water use of UHPC, are provided for the first time by this article. UHPC shows relative lower footprint values when the use phase is considered. However, higher environmental impacts are shown within the end-of-life phase according to the high compressive strength. Policies and standards related to UHPC use need to be developed according to the current increase in the usage of new concrete technologies. Because of the relative high cost of UHPC, an economic analysis, e.g., life cycle costing of UHPC in comparison with CC, could be a crucial issue to be considered for future studies.

Author Contributions: V.W. collected the data and performed the calculations as part of her Bachelor thesis. H.S. reviewed and recalculate the results and wrote the article. C.M. initiated and coordinated the work. S.B. gave a valuable guidance on the footprint assessment scenarios. E.F. gave valuable feedback on the use of UHPC and provided information for the case study. A.W. gave valuable contributions on the mixtures and usages of the UHPC and CC. All the authors read and approved the final manuscript.

Funding: This research received no external funding.

Acknowledgments: The authors would like to thank Anna Schomberg for her valuable comments on the AWARE method.

Conflicts of Interest: The authors declare no conflict of interest.

\section{Appendix A}

Appendix A.1. Life Cycle Inventory of UHPC

Table A1. Life cycle inventory of $1 \mathrm{~m}^{3}$ of ready-mix (M3Q) UHPC using GaBi construction materials database for A1-A3 life cycle stages.

\begin{tabular}{cccl}
\hline Flow & Quantity & Unit & \multicolumn{1}{c}{ Process } \\
\hline Cement (CEM I) & 775.00 & $\mathrm{~kg}$ & $\begin{array}{l}\text { Cement (CEM I 52.5) (EN15804 A1-A3), production mix, } \\
\text { at plant, technology mix, CEM I 52.5, DE }\end{array}$ \\
\hline Quartz sand (0/2) & 946.00 & $\mathrm{~kg}$ & $\begin{array}{l}\text { Silica sand (Excavation and processing), production mix, } \\
\text { at plant, technology mix, sand, diameter < 2 mm, DE }\end{array}$ \\
\hline $\begin{array}{c}\text { Very fine milled silica sand } \\
\text { d50 = 20 micrometer }\end{array}$ & 193.00 & $\mathrm{~kg}$ & $\begin{array}{l}\text { Very fine milled silica sand d50 = 20 micrometer, at plant, } \\
\text { Production, median diameter of silica sand grains is } \\
\text { 20 micrometers, EU-27 }\end{array}$ \\
\hline
\end{tabular}


Table A1. Cont.

\begin{tabular}{cccl}
\hline Flow & Quantity & Unit & \multicolumn{1}{c}{ Process } \\
\hline Plasticizer & 23.50 & $\mathrm{~kg}$ & $\begin{array}{l}\text { Concrete admixtures Plasticizer and } \\
\text { superplasticizer-Deutsche Bauchemie e.V. (DBC) (A1-A3), } \\
\text { production mix, association/model EPD, valid for Germany, } \\
\text { technology mix, 1 kg; density: 1-1.6 kg/, DE }\end{array}$ \\
\hline Water, ground & 183.00 & $\mathrm{~kg}$ & - \\
\hline Transporting capacity & $7.31^{*}$ & $\mathrm{tkm}$ & $\begin{array}{l}\text { Transportation by rail (EN15804 A4), production mix, at plant, } \\
\text { technology mix, DE }\end{array}$ \\
\hline Transporting capacity & $9.20^{* *}$ & $\mathrm{tkm}$ & $\begin{array}{l}\text { Container ship (EN15804 A4), production mix, at plant, } \\
\text { technology mix, heavy fuel oil driven, cargo, Average, DE }\end{array}$ \\
\hline Transporting capacity & $398.58^{* * *}$ & $\mathrm{tkm}$ & $\begin{array}{l}\text { Truck (EN15804 A4), production mix, at plant, } \\
\text { technology mix, DE }\end{array}$ \\
\hline Electricity & 7.09 & $\mathrm{kWh}$ & $\begin{array}{l}\text { Electricity grid mix 1 kV-60 kV, consumption mix, to } \\
\text { consumer, AC, technology mix, 1 kV-60 kV, DE }\end{array}$ \\
\hline Light fuel oil & 0.21 & $\mathrm{~kg}$ & $\begin{array}{l}\text { Light fuel oil at refinery (EN15804 B6), production mix, } \\
\text { at refinery, from crude oil, 0.1 wt.\% sulphur, DE }\end{array}$ \\
\hline Diesel & 0.07 & $\mathrm{~kg}$ & $\begin{array}{l}\text { Diesel mix at filling station, consumption mix, at filling } \\
\text { station, from crude oil and bio components, 8.37 wt.\% bio } \\
\text { components, DE }\end{array}$ \\
\hline Micro steel fibers & 192 & $\mathrm{~kg}$ & \begin{tabular}{l} 
See production of 1 kg micro steel fibers \\
\hline
\end{tabular}
\end{tabular}

Calculations of the transport: * Rail: $8.9 \%$ of the cement $0.089 \cdot 0.775 \mathrm{t} \cdot 106 \mathrm{~km}=7.31 \mathrm{tkm}$; ${ }^{* *}$ Ship: $11.2 \%$ of the cement $0.112 \cdot 0.775 \mathrm{t} \cdot 106 \mathrm{~km}=9.20 \mathrm{tkm}$; ${ }^{* * *}$ Truck: rest percentage of cement and other materials: $0.799 \cdot 0.775 \mathrm{t} \cdot 106 \mathrm{~km}+$ $0.164 \mathrm{t} \cdot 700 \mathrm{~km}+0.192 \mathrm{t} \cdot 230 \mathrm{~km}+0.0313 \mathrm{t} \cdot 100 \mathrm{~km}+1.139 \mathrm{t} \cdot 150 \mathrm{~km}=398.58 \mathrm{tkm}$.

Table A2. Life cycle inventory of $1 \mathrm{~m}^{3}$ of precast (M2Q) UHPC using GaBi construction materials database for A1-A3 life cycle stages.

\begin{tabular}{|c|c|c|c|}
\hline Flow & Quantity & Unit & Process \\
\hline Cement (CEM I) & 832.00 & $\mathrm{~kg}$ & $\begin{array}{l}\text { Cement (CEM I 52.5) (EN15804 A1-A3), production mix, } \\
\text { at plant, technology mix, CEM I 52.5, DE }\end{array}$ \\
\hline Quartz sand $(0 / 2)$ & 975.00 & $\mathrm{~kg}$ & $\begin{array}{l}\text { Silica sand (Excavation and processing), production mix, } \\
\text { at plant, technology mix, sand, diameter }<2 \mathrm{~mm}, \mathrm{DE}\end{array}$ \\
\hline $\begin{array}{l}\text { Very fine milled silica sand } \\
\qquad \mathrm{d} 50=20 \text { micrometer }\end{array}$ & 207.00 & $\mathrm{~kg}$ & $\begin{array}{l}\text { Very fine milled silica sand d } 50=20 \text { micrometer, at plant, } \\
\text { Production, median diameter of silica sand grains is } \\
20 \text { micrometers, EU-27 }\end{array}$ \\
\hline Plasticizer & 29.40 & $\mathrm{~kg}$ & $\begin{array}{l}\text { Concrete admixtures Plasticizer and } \\
\text { superplasticizer-Deutsche Bauchemie e.V. (DBC) (A1-A3), } \\
\text { production mix, association / model EPD, valid for Germany, } \\
\text { technology mix, } 1 \mathrm{~kg} \text {; density: } 1-1.6 \mathrm{~kg} / \mathrm{l} \text {, DE }\end{array}$ \\
\hline Water, ground & 166.00 & $\mathrm{~kg}$ & - \\
\hline Transporting capacity & $7.85^{*}$ & $\mathrm{tkm}$ & $\begin{array}{l}\text { Transportation by rail (EN15804 A4), production mix, at plant, } \\
\text { technology mix, DE }\end{array}$ \\
\hline Transporting capacity & $9.88^{* *}$ & $\mathrm{tkm}$ & $\begin{array}{l}\text { Container ship (EN15804 A4), production mix, at plant, } \\
\text { technology mix, heavy fuel oil driven, cargo, Average, DE }\end{array}$ \\
\hline Transporting capacity & $389.37^{* * *}$ & $\mathrm{tkm}$ & $\begin{array}{l}\text { Truck (EN15804 A4), production mix, at plant, } \\
\text { technology mix, DE }\end{array}$ \\
\hline Electricity & 26.42 & MJ & $\begin{array}{l}\text { Electricity grid mix } 1 \mathrm{kV}-60 \mathrm{kV} \text {, consumption mix, to } \\
\text { consumer, AC, technology mix, } 1 \mathrm{kV}-60 \mathrm{kV} \text {, DE }\end{array}$ \\
\hline Light fuel oil & 2.73 & $\mathrm{~kg}$ & $\begin{array}{l}\text { Light fuel oil at refinery (EN15804 B6), production mix, } \\
\text { at refinery, from crude oil, } 0.1 \mathrm{wt} . \% \text { sulphur, DE }\end{array}$ \\
\hline Diesel & 0.07 & $\mathrm{~kg}$ & $\begin{array}{l}\text { Diesel mix at filling station, consumption mix, at filling } \\
\text { station, from crude oil and bio components, } 8.37 \mathrm{wt} . \% \text { bio } \\
\text { components, DE }\end{array}$ \\
\hline Micro steel fibers & 192 & $\mathrm{~kg}$ & See production of $1 \mathrm{~kg}$ micro steel fibers \\
\hline
\end{tabular}

Calculations of the transport: * Rail: $8.9 \%$ of the cement $0.089 \cdot 0.832 \mathrm{t} \cdot 106 \mathrm{~km}=7.85 \mathrm{tkm}$; ${ }^{* *}$ Ship: $11.2 \%$ of the cement

$0.112 \cdot 0.832 \mathrm{t} \cdot 106 \mathrm{~km}=9.88 \mathrm{tkm} ; * * *$ Truck: Rest percentage of cement and rest materials $0.799 \cdot 0.832 \mathrm{t} \cdot 106 \mathrm{~km}+$

$0.135 \mathrm{t} \cdot 700 \mathrm{~km}+0.192 \mathrm{t} \cdot 230 \mathrm{~km}+0.0294 \mathrm{t} \cdot 100 \mathrm{~km}+1.182 \mathrm{t} \cdot 150 \mathrm{~km}=389.37 \mathrm{tkm}$. 
Table A3. Life cycle inventory of $1 \mathrm{~kg}$ micro steel fibers using ecoinvent 3.1 cut-off database.

\begin{tabular}{|c|c|c|c|c|}
\hline Description & Flow & Quantity & Unit & Process \\
\hline $\begin{array}{l}\text { crude steel } \\
\text { production }\end{array}$ & steel, low-alloyed, RER & 1.005362 & $\mathrm{~kg}$ & $\begin{array}{l}\text { steel production, converter, low-alloyed, } \\
\text { cut-off, U, RER }\end{array}$ \\
\hline Hot rolling to wire & Hot rolling, steel, RER & 1.005362 & $\mathrm{~kg}$ & hot rolling, steel, cut-off, U, RER \\
\hline \multirow{2}{*}{ Descaling } & Electricity, low voltage, DE & 0.0357 & kWh & $\begin{array}{l}\text { BKV: electricity voltage transformation } \\
\text { from medium to low voltage, grid } 2030\end{array}$ \\
\hline & $\begin{array}{l}\text { Industrial machine, heavy, } \\
\text { unspecified, RER }\end{array}$ & $1.42 \times 10^{-5}$ & $\mathrm{~kg}$ & $\begin{array}{l}\text { industrial machine production, heavy, } \\
\text { unspecified, cut-off, U, RER }\end{array}$ \\
\hline \multirow{3}{*}{ Dry drawing } & Electricity, low voltage, DE & 0.114 & $\mathrm{kWh}$ & $\begin{array}{l}\text { BKV: electricity voltage transformation } \\
\text { from medium to low voltage, grid } 2030\end{array}$ \\
\hline & $\begin{array}{l}\text { Industrial machine, heavy, } \\
\text { unspecified, RER }\end{array}$ & $1.38 \times 10^{-4}$ & $\mathrm{~kg}$ & $\begin{array}{l}\text { industrial machine production, heavy, } \\
\text { unspecified, cut-off, U, RER }\end{array}$ \\
\hline & Soap, RER & 0.012 & $\mathrm{~kg}$ & soap production, cut-off, U, RER \\
\hline \multirow{4}{*}{ wet drawing } & Electricity, low voltage, DE & 2.452 & kWh & $\begin{array}{l}\text { BKV: electricity voltage transformation } \\
\text { from medium to low voltage, grid } 2030\end{array}$ \\
\hline & $\begin{array}{l}\text { Industrial machine, heavy, } \\
\text { unspecified, RER }\end{array}$ & $9.74 \times 10^{-4}$ & $\mathrm{~kg}$ & $\begin{array}{l}\text { industrial machine production, heavy, } \\
\text { unspecified, cut-off, U, RER }\end{array}$ \\
\hline & Lubricating oil, RER & 0.002 & $\mathrm{~kg}$ & lubricating oil production, cut-off, U, RER \\
\hline & $\begin{array}{c}\text { Tap water, Europe without } \\
\text { Switzerland }\end{array}$ & 0.02 & $\mathrm{~kg}$ & $\begin{array}{l}\text { market for tap water, cut-off, U, Europe } \\
\text { without Switzerland }\end{array}$ \\
\hline \multirow{2}{*}{ Annealing } & Electricity, low voltage, DE & 0.126 & kWh & $\begin{array}{l}\text { BKV: electricity voltage transformation } \\
\text { from medium to low voltage, grid } 2030\end{array}$ \\
\hline & $\begin{array}{l}\text { Industrial machine, heavy, } \\
\text { unspecified, RER }\end{array}$ & $2.28 \times 10^{-4}$ & $\mathrm{~kg}$ & $\begin{array}{l}\text { industrial machine production, heavy, } \\
\text { unspecified, cut-off, U, RER }\end{array}$ \\
\hline \multirow{2}{*}{ stranding } & Electricity, low voltage, DE & 0.937 & $\mathrm{kWh}$ & $\begin{array}{l}\text { BKV: electricity voltage transformation } \\
\text { from medium to low voltage, grid } 2030\end{array}$ \\
\hline & $\begin{array}{l}\text { Industrial machine, heavy, } \\
\text { unspecified, RER }\end{array}$ & $2.60 \cdot 10^{-3}$ & $\mathrm{~kg}$ & $\begin{array}{l}\text { industrial machine production, heavy, } \\
\text { unspecified, cut-off, U, RER }\end{array}$ \\
\hline \multirow{2}{*}{ Cutting } & Electricity, low voltage, DE & 0.033 & $\mathrm{kWh}$ & $\begin{array}{l}\text { BKV: electricity voltage transformation } \\
\text { from medium to low voltage, grid } 2030\end{array}$ \\
\hline & $\begin{array}{l}\text { Industrial machine, heavy, } \\
\text { unspecified, RER }\end{array}$ & $1.56 \times 10^{-4}$ & $\mathrm{~kg}$ & $\begin{array}{l}\text { industrial machine production, heavy, } \\
\text { unspecified, cut-off, U, RER }\end{array}$ \\
\hline
\end{tabular}

\section{Appendix A.2. Life Cycle Inventory of Conventional Concrete}

Table A4. Life cycle inventory of $1 \mathrm{~m}^{3}$ of ready-mix concrete C35/45 using GaBi construction materials database for A1-A3 life cycle stages.

\begin{tabular}{|c|c|c|c|}
\hline Flow & Quantity & Unit & Process \\
\hline Cement (CEM II/A) & 356.00 & $\mathrm{~kg}$ & $\begin{array}{l}\text { Cement (CEM II/A) (EN15804 A1-A3), production mix, } \\
\text { at plant, technology mix, CEM II/A, DE }\end{array}$ \\
\hline Gravel (2/32) & 1168.00 & $\mathrm{~kg}$ & $\begin{array}{l}\text { Gravel grain } 2-32 \mathrm{~mm} \text {, production mix, at plant, technology } \\
\text { mix, dried, DE }\end{array}$ \\
\hline Plasticizer & 1.80 & $\mathrm{~kg}$ & $\begin{array}{l}\text { Concrete admixtures plasticizer and superplasticizer - } \\
\text { Deutsche Bauchemie e.V. (DBC) (A1-A3), production mix, } \\
\text { association/model EPD, valid for Germany, technology mix, } \\
1 \mathrm{~kg} \text {; density: } 1-1.6 \mathrm{~kg} / \mathrm{l} \mathrm{DE}\end{array}$ \\
\hline Sand $(0 / 2)$ & 640.00 & $\mathrm{~kg}$ & $\begin{array}{l}\text { Sand grain } 0-2 \mathrm{~mm} \text { (dried) (EN15804 A1-A3), production mix, } \\
\text { at plant, technology mix, grain size } 0-2 \mathrm{~mm}, \mathrm{DE}\end{array}$ \\
\hline Water & 165.00 & $\mathrm{~kg}$ & - \\
\hline Transporting capacity & $4.70 *$ & $\mathrm{tkm}$ & $\begin{array}{l}\text { Transportation by rail (EN15804 A4), production mix, at plant, } \\
\text { technology mix, DE }\end{array}$ \\
\hline Transporting capacity & $11.35 * *$ & $\mathrm{tkm}$ & $\begin{array}{l}\text { Container ship (EN15804 A4), production mix, at plant, } \\
\text { technology mix, heavy fuel oil driven, cargo, Average, DE }\end{array}$ \\
\hline Transporting capacity & $97.08^{* * *}$ & $\mathrm{tkm}$ & $\begin{array}{l}\text { Truck (EN15804 A4), production mix, at plant, } \\
\text { technology mix, DE }\end{array}$ \\
\hline
\end{tabular}


Table A4. Cont.

\begin{tabular}{cccl}
\hline Flow & Quantity & Unit & \multicolumn{1}{c}{ Process } \\
\hline Electricity & 4.43 & $\mathrm{kWh}$ & $\begin{array}{l}\text { Electricity grid mix } 1 \mathrm{kV}-60 \mathrm{kV}, \text { consumption mix, to } \\
\text { consumer, AC, technology mix, 1 kV-60 kV, DE }\end{array}$ \\
\hline Light fuel oil & 0.21 & $\mathrm{~kg}$ & $\begin{array}{l}\text { Light fuel oil at refinery (EN15804 B6), production mix, } \\
\text { at refinery, from crude oil, 0.1 wt.\% sulphur, DE }\end{array}$ \\
\hline Diesel & 0.07 & $\mathrm{~kg}$ & $\begin{array}{l}\text { Diesel mix at filling station, consumption mix, at filling } \\
\text { station, from crude oil and bio components, 8.37 wt.\% bio } \\
\text { components, DE }\end{array}$ \\
\hline
\end{tabular}

Calculations of the transport: ${ }^{*}$ Rail: $1.9 \%$ of the aggregate, $8.9 \%$ of the cement $0.019 \cdot 1.808 \mathrm{t} \cdot 39 \mathrm{~km}+$ $0.089 \cdot 0.356 \mathrm{t} \cdot 106 \mathrm{~km}=4.70 \mathrm{tkm}$; $* *$ Ship: $10.1 \%$ of the aggregate, $11.2 \%$ of the cement $0.101 \cdot 1.808 \mathrm{t} \cdot 39 \mathrm{~km}+$ $0.112 \cdot 0.356 \mathrm{t} \cdot 106 \mathrm{~km}=11.35 \mathrm{tkm} ;{ }^{* * *}$ ruck: Rest $0.88 \cdot 1.808 \mathrm{t} \cdot 39 \mathrm{~km}+0.799 \cdot 0.356 \mathrm{t} \cdot 106 \mathrm{~km}+0.047 \mathrm{t} \cdot 100 \mathrm{~km}+$ $0.0018 \mathrm{t} \cdot 100 \mathrm{~km}=97.08 \mathrm{tkm}$.

Table A5. Life cycle inventory of $1 \mathrm{~m}^{3}$ of precast concrete C50/60 using GaBi construction materials database for A1-A3 life cycle stages.

\begin{tabular}{|c|c|c|c|}
\hline Flow & Quantity & Unit & Process \\
\hline Cement (CEM II/A) & 405.00 & $\mathrm{~kg}$ & $\begin{array}{l}\text { Cement (CEM II/A) (EN15804 A1-A3), production mix, } \\
\text { at plant, technology mix, CEM II/A, DE }\end{array}$ \\
\hline Gravel (2/32) & 1198.00 & $\mathrm{~kg}$ & $\begin{array}{l}\text { Gravel grain } 2-32 \mathrm{~mm} \text {, production mix, at plant, technology } \\
\text { mix, dried, DE }\end{array}$ \\
\hline Plasticizer & 4.60 & $\mathrm{~kg}$ & $\begin{array}{l}\text { Concrete admixtures Plasticizer and superplasticizer, } \\
\text { Deutsche Bauchemie e.V. (DBC) (A1-A3), production mix, } \\
\text { association } / \text { model EPD, valid for Germany, technology mix, } \\
1 \mathrm{~kg} \text {; density: } 1-1.6 \mathrm{~kg} / \mathrm{lDE}\end{array}$ \\
\hline Sand $(0 / 2)$ & 654.00 & $\mathrm{~kg}$ & $\begin{array}{l}\text { Sand grain 0-2 mm (dried) (EN15804 A1-A3), production mix, } \\
\text { at plant, technology mix, grain size 0-2 mm, DE }\end{array}$ \\
\hline Water & 141.00 & $\mathrm{~kg}$ & - \\
\hline Transporting capacity & $5.19^{*}$ & $\mathrm{tkm}$ & $\begin{array}{l}\text { Transportation by rail (EN15804 A4), production mix, at plant, } \\
\text { technology mix, DE }\end{array}$ \\
\hline Transporting capacity & 12.10 ** & $\mathrm{tkm}$ & $\begin{array}{l}\text { Container ship (EN15804 A4), production mix, at plant, } \\
\text { technology mix, heavy fuel oil driven, cargo, Average, DE }\end{array}$ \\
\hline Transporting capacity & $100.82^{* * *}$ & $\mathrm{tkm}$ & $\begin{array}{l}\text { Truck (EN15804 A4), production mix, at plant, } \\
\text { technology mix, DE }\end{array}$ \\
\hline Electricity & 16.85 & MJ & $\begin{array}{l}\text { Electricity grid mix } 1 \mathrm{kV}-60 \mathrm{kV} \text {, consumption mix, to } \\
\text { consumer, AC, technology mix, } 1 \mathrm{kV}-60 \mathrm{kV} \text {, DE }\end{array}$ \\
\hline Light fuel oil & 2.73 & $\mathrm{~kg}$ & $\begin{array}{l}\text { Light fuel oil at refinery (EN15804 B6), production mix, } \\
\text { at refinery, from crude oil, } 0.1 \mathrm{wt} \text {.\% sulphur, DE }\end{array}$ \\
\hline Diesel & 0.07 & $\mathrm{~kg}$ & $\begin{array}{l}\text { Diesel mix at filling station, consumption mix, at filling } \\
\text { station, from crude oil and bio components, } 8.37 \text { wt. } \% \text { bio } \\
\text { components, DE }\end{array}$ \\
\hline
\end{tabular}

Calculations of the transport: ${ }^{*}$ Rail: $1.9 \%$ of the Aggregate, $8.9 \%$ of the cement $0.019 \cdot 1.852 \mathrm{t} \cdot 39 \mathrm{~km}+$ $0.089 \cdot 0.405 \mathrm{t} \cdot 106 \mathrm{~km}=5.19 \mathrm{tkm}$; * Ship: $10.1 \%$ of the aggregate, $11.2 \%$ of the cement $0.101 \cdot 1.852 \mathrm{t} \cdot 39 \mathrm{~km}+$ $0.112 \cdot 0.405 \mathrm{t} \cdot 106 \mathrm{~km}=12.10 \mathrm{tkm} ;{ }^{* * *}$ Truck: Rest 0.88.1.852 t.39 km + 0.799.0.405 t.106 km + 0.025 t.100 km + $0.0046 \mathrm{t} \cdot 100 \mathrm{~km}=100.82 \mathrm{tkm}$

Appendix A.3. Life Cycle Inventory of Transport to Construction Site (A4 Life Cycle Stage) and Construction (A5 Life Cycle Stage)

Table A6. Life cycle inventory of the transportation (A4 life cycle stage) of C35/45 and M3Q using GaBi construction materials database.

\begin{tabular}{cccc}
\hline Flow & Quantity & Unit & Process \\
\hline $\begin{array}{c}\text { Transporting } \\
\text { capacity } \\
\text { Diesel }\end{array}$ & $281.99 *$ & $\mathrm{tkm}$ & $\begin{array}{l}\text { Truck (EN15804 A4), production mix, at plant, technology mix, DE } \\
\text { Diesel mix at filling station, consumption mix, at filling station, from } \\
\text { crude oil and bio components, } 8.37 \mathrm{wt} \% \text { bio components, DE }\end{array}$ \\
\hline $\begin{array}{l}*: 2 \text { way }{ }^{*} 0.5 \mathrm{utilization} * \\
\mathrm{~L} / \mathrm{km} \cdot 0.845 \mathrm{~kg} / \mathrm{L} \cdot 16.3 \mathrm{~km}=1.79 \mathrm{~kg} .\end{array}$ & $\mathrm{kg}$ & $17.3 \mathrm{t}=281.99 \mathrm{tkm}$. Transport quantity: $\frac{17.3 \mathrm{t}}{2.4 \mathrm{t} / \mathrm{m}^{3}}=7.5 \mathrm{~m}^{3} ; * *:(0.48-0.35)$
\end{tabular}


Table A7. Life cycle inventory of the transportation processes (A4 life cycle stage) of C50/60 and M2Q using GaBi construction materials database.

\begin{tabular}{cccc}
\hline Flow & Quantity & Unit & Process \\
\hline $\begin{array}{c}\text { Transporting } \\
\text { capacity }\end{array}$ & $4860.00 *$ & $\mathrm{tkm}$ & Road train (EN15804 A4), production mix, at plant, technology mix, DE \\
\hline & $*: 2$ & way* 0.5 utilization $* 180 \mathrm{~km} \cdot 27 \mathrm{t}=4860.00 \mathrm{tkm}$; Transport quantity: $\frac{27 \mathrm{t}}{2.4 \mathrm{t} / \mathrm{m}^{3}}=11 \mathrm{~m}^{3}$.
\end{tabular}

Table A8. Life cycle inventory of the construction processes (A5 life cycle stage) using GaBi construction materials database.

\begin{tabular}{ccccl}
\hline Type of Concrete & Flow & Quantity & Unit & \multicolumn{1}{c}{ Process } \\
\hline C35/45 & Electricity & 0.90 & MJ & $\begin{array}{l}\text { Electricity grid mix } 1 \mathrm{kV}-60 \mathrm{kV}, \text { consumption mix, to } \\
\text { consumer, AC, technology mix, 1 kV-60 kV, DE }\end{array}$ \\
\hline M3Q & Diesel & 0.33 & $\mathrm{~kg}$ & $\begin{array}{l}\text { Diesel mix at filling station, consumption mix, at filling } \\
\text { station, from crude oil and bio components, 8.37 wt. } \% \\
\text { bio components, DE }\end{array}$ \\
\hline C50/60 M2Q & Electricity & 19.20 & MJ & $\begin{array}{l}\text { Electricity grid mix 1 kV-60 kV, consumption mix, } \\
\text { to consumer, AC, technology mix, 1 kV-60 kV, DE }\end{array}$ \\
\hline
\end{tabular}

Appendix A.4. Life Cycle Inventory of C1-C3 Life Cycle Stages

Table A9. Life cycle inventory of the demolishing processes (C1 life cycle stage) using GaBi construction materials database.

\begin{tabular}{ccccl}
\hline Type of Concrete & Flow & Quantity & Unit & Process \\
\hline CC & \multirow{2}{*}{ Diesel } & 0.51 & \multirow{2}{*}{$\mathrm{kg}$} & $\begin{array}{l}\text { Diesel mix at filling station, consumption mix, at filling station, from } \\
\text { crude oil and bio components, 8.37 wt.\% bio components, DE }\end{array}$ \\
\hline
\end{tabular}

Table A10. Life cycle inventory of the construction waste transport (C2 life cycle stage) using GaBi construction materials database.

\begin{tabular}{|c|c|c|c|}
\hline Flow & Quantity & Unit & Process \\
\hline Transporting capacity & $810.00 *$ & $\mathrm{tkm}$ & $\begin{array}{l}\text { Road train (EN15804 A4), production mix, at plant, } \\
\text { technology mix, DE }\end{array}$ \\
\hline
\end{tabular}

Table A11. Life cycle inventory of the construction waste treatment (C3 life cycle stage) using GaBi construction materials database.

\begin{tabular}{|c|c|c|c|c|}
\hline Type of Concrete & Flow & Quantity & Unit & Process \\
\hline $\mathrm{CC}$ & \multirow{2}{*}{ Electricity } & 18.26 & \multirow{2}{*}{ MJ } & \multirow{2}{*}{$\begin{array}{l}\text { Electricity grid mix } 1 \mathrm{kV}-60 \mathrm{kV} \text {, consumption mix, to consumer, } \mathrm{AC} \text {, } \\
\text { technology mix, } 1 \mathrm{kV}-60 \mathrm{kV}, \mathrm{DE}\end{array}$} \\
\hline UHPC & & 21.21 & & \\
\hline $\mathrm{CC}$ & \multirow{2}{*}{ Diesel } & 0.76 & \multirow{2}{*}{$\mathrm{kg}$} & \multirow{2}{*}{$\begin{array}{l}\text { Diesel mix at filling station, consumption mix, at filling station, from } \\
\text { crude oil and bio components, } 8.37 \text { wt.\% bio components, DE }\end{array}$} \\
\hline UHPC & & 0.87 & & \\
\hline
\end{tabular}

\section{Appendix B. Life Cycle Inventory of the Sensitivity Analysis}

For the sensitivity analysis, cement type is changed for all mixtures of UHPC and CC, in addition to changing type of production process of steel fibers for UHPC mixture.

Table A12. Processes descriptions of the cement type CEM III/A and steel electric production.

\begin{tabular}{ccc}
\hline Material & Process & Database \\
\hline CEM III/A & $\begin{array}{c}\text { Cement (CEM III A) (EN15804 A1-A3), production } \\
\text { mix, at plant, technology mix, CEM III A }\end{array}$ & $\begin{array}{c}\text { GaBi construction material } \\
\text { database }\end{array}$ \\
\hline steel (electric production) & steel production, electric, low-alloyed, cut-off, U & Ecoinvent 3.1 database \\
\hline
\end{tabular}




\section{Appendix C. Life Cycle Inventory of The Case Study}

\section{Appendix C.1. Life Cycle Inventory for A1-A3 Life Cycle Stages}

Table A13. Life cycle inventory of A1-A3 of the CC bridge design, using GaBi construction material database.

\begin{tabular}{|c|c|c|c|}
\hline Material & Quantity & Unit & Process \\
\hline Bitumen & 169.54 & $\mathrm{~kg}$ & $\begin{array}{l}\text { Bitumen at refinery, production mix, at refinery, from crude } \\
\text { oil, DE }\end{array}$ \\
\hline Bitumen sheets & 3064.36 & $\mathrm{~kg}$ & $\begin{array}{l}\text { Bitumen sheets PYE-PV } 200 \text { S5 (not slated) }(\mathrm{EN} 15804 \mathrm{~A} 1-\mathrm{A} 3) \text {, } \\
\text { production mix, at plant, technology mix, 5,2 kg/m², DE }\end{array}$ \\
\hline Bitumen sheets & 30.42 & $\mathrm{~kg}$ & $\begin{array}{l}\text { Bitumen sheet v } 60(\mathrm{EN} 15804 \mathrm{~A} 1-\mathrm{A} 3) \text {, production mix, } \\
\text { at plant, technology mix, } 5 \mathrm{~kg} / \mathrm{m}^{2}, \mathrm{DE}\end{array}$ \\
\hline Quartz sand $(0 / 2)$ & 843.00 & $\mathrm{~kg}$ & $\begin{array}{l}\text { Silica sand (Excavation and processing), production mix, } \\
\text { at plant, technology mix, sand, diameter }<2 \mathrm{~mm}, \mathrm{DE}\end{array}$ \\
\hline $\mathrm{C} 25 / 30, \mathrm{~A} 1-\mathrm{A} 3$ & 59.00 & $\mathrm{~m}^{3}$ & $\mathrm{C} 25 / 30, \mathrm{~A} 1-\mathrm{A} 3$ \\
\hline $\mathrm{C} 35 / 45, \mathrm{~A} 1-\mathrm{A} 3$ & 159.00 & $\mathrm{~m}^{3}$ & $\mathrm{C} 35 / 45, \mathrm{~A} 1-\mathrm{A} 3$ \\
\hline $\mathrm{C} 50 / 60, \mathrm{~A} 1-\mathrm{A} 3$ & 142.00 & $\mathrm{~m}^{3}$ & $\mathrm{C} 50 / 60, \mathrm{~A} 1-\mathrm{A} 3$ \\
\hline Epoxy resin & 562.00 & $\mathrm{~kg}$ & $\begin{array}{l}\text { Epoxy Resin (EP) Mix, consumption mix, to consumer, from } \\
\text { Bisphenol A and epichlorohydrin, approx. } 1.15 \mathrm{~g} / \mathrm{cm}^{3}, \mathrm{DE}\end{array}$ \\
\hline $\begin{array}{l}\text { Melted asphalt, } \\
\text { integrated }\end{array}$ & 56.45 & $\mathrm{t}$ & $\begin{array}{l}\text { Mastic asphalt (EN15804 A1-A3), production mix, at plant, } \\
\text { technology mix, } 2400 \mathrm{~kg} / \mathrm{m} 3, \mathrm{DE}\end{array}$ \\
\hline Split (2/15) & 1950.00 & $\mathrm{~kg}$ & $\begin{array}{l}\text { Crushed stone grain 2-15 mm (EN15804 A1-A3), production } \\
\text { mix, at plant, technology mix, dried, DE }\end{array}$ \\
\hline Steel wire & 68.00 & $\mathrm{t}$ & $\begin{array}{l}\text { Reinforced steel (wire) (EN15804 A1-A3), production mix, } \\
\text { at plant, EAF route, wire, DE }\end{array}$ \\
\hline
\end{tabular}

Table A14. Life cycle inventory of A1-A3 of the UHPC bridge design using GaBi construction material database.

\begin{tabular}{|c|c|c|c|}
\hline Material & Quantity & Unit & Process \\
\hline Bitumen & 96.58 & $\mathrm{~kg}$ & $\begin{array}{l}\text { Bitumen at refinery, production mix, at refinery, from crude } \\
\text { oil, DE }\end{array}$ \\
\hline $\mathrm{C} 35 / 45, \mathrm{~A} 1-\mathrm{A} 3$ & 25.00 & $\mathrm{~m}^{3}$ & $\mathrm{C} 35 / 45, \mathrm{~A} 1-\mathrm{A} 3$ \\
\hline $\mathrm{C} 50 / 60, \mathrm{~A} 1-\mathrm{A} 3$ & 180.00 & $\mathrm{~m}^{3}$ & $\mathrm{C} 50 / 60, \mathrm{~A} 1-\mathrm{A} 3$ \\
\hline Crushed sand $(0 / 2)$ & 900.00 & $\mathrm{~kg}$ & $\begin{array}{l}\text { Limestone, crushed stone fines (Grain size } 0 / 4)(\mathrm{EN} 15804 \\
\mathrm{A} 1-\mathrm{A} 3) \text {, production mix, at plant, technology mix, grain size } \\
0 / 4, \mathrm{DE}\end{array}$ \\
\hline Epoxy resin & 1.24 & $\mathrm{t}$ & $\begin{array}{l}\text { Epoxy Resin (EP) Mix, consumption mix, to consumer, from } \\
\text { Bisphenol A and epichlorohydrin, approx. } 1.15 \mathrm{~g} / \mathrm{cm}^{3}, \mathrm{DE}\end{array}$ \\
\hline $\begin{array}{l}\text { Melted asphalt, } \\
\text { integrated }\end{array}$ & 1.73 & $\mathrm{t}$ & $\begin{array}{l}\text { Mastic asphalt (EN15804 A1-A3), production mix, at plant, } \\
\text { technology mix, } 2400 \mathrm{~kg} / \mathrm{m}^{3}, \mathrm{DE}\end{array}$ \\
\hline Sikaflex-651 S LVP & 122.85 & $\mathrm{~kg}$ & $\begin{array}{l}\text { PUR sealing compound (EN15804 A1-A3), production mix, } \\
\text { at plant, technology mix, PUR, DE }\end{array}$ \\
\hline Steel wire & 61.90 & $\mathrm{t}$ & $\begin{array}{l}\text { Reinforced steel (wire) (EN15804 A1-A3), production mix, } \\
\text { at plant, EAF route, wire, DE }\end{array}$ \\
\hline Stone mastic asphalt & 28.80 & $\mathrm{t}$ & $\begin{array}{l}\text { Stone mastic asphalt SMA (EN15804 A1-A3), production mix, } \\
\text { at plant, technology mix, SMA, DE }\end{array}$ \\
\hline $\begin{array}{l}\mathrm{UHPC} \mathrm{M} 2 \mathrm{Q}, \mathrm{A} 1-\mathrm{A} 3, \\
\text { ready-mix concrete }\end{array}$ & 1.10 & $\mathrm{~m}^{3}$ & UHPC M2Q, A1-A3, Transport \\
\hline UHPC M2Q, A1-A3 & 33.00 & $\mathrm{~m}^{3}$ & UHPC M2Q, A1-A3 \\
\hline UHPC M3Q+, A1-A3 & 27.50 & $\mathrm{~m}^{3}$ & UHPC M3Q+, A1-A3 \\
\hline Micro steel fibers & $11.83 *$ & $\mathrm{t}$ & See input data for production of $1 \mathrm{~kg}$ steel fibers \\
\hline
\end{tabular}

Process of steel fibers calculated separately with ecoinvent database and results added afterwards. $* \frac{192 \mathrm{~kg} \text { steel fibers }}{\mathrm{m}^{3} \mathrm{UHPC}} \cdot(33.00+27.50+1.1) \mathrm{m}^{3}=11827.2 \mathrm{~kg}=11.83 \mathrm{t}$. 
Appendix C.2. Life Cycle Inventory of A4 LIFE CYCLE STAGE

Table A15. Transport details of CC bridge design.

\begin{tabular}{|c|c|c|c|c|c|c|c|}
\hline \multirow{2}{*}{ Material } & \multirow{2}{*}{ Quantity } & \multirow{2}{*}{$\begin{array}{l}\text { Means of } \\
\text { Transport }\end{array}$} & \multirow{2}{*}{$\frac{\text { Trips }}{\text { (Quantity) }}$} & \multirow{2}{*}{$\begin{array}{c}\text { Utilization } \\
(\%)\end{array}$} & \multirow{2}{*}{$\begin{array}{c}\text { Distance } \\
(\mathbf{k m})\end{array}$} & \multirow{2}{*}{$\begin{array}{c}\text { Payload } \\
(t)\end{array}$} & \multirow[t]{2}{*}{ Transport Capacity } \\
\hline & & & & & & & \\
\hline \multirow{2}{*}{$\mathrm{C} 35 / 45$} & \multirow{2}{*}{$159.00 \mathrm{~m}^{3}$} & \multirow{2}{*}{ Truck } & 42 & 50 & 16.3 & 17.3 & \multirow{2}{*}{$5978.19 \mathrm{tkm}+39.38 \mathrm{~kg}$ Diesel } \\
\hline & & & 2 & 10 & 16.3 & 17.3 & \\
\hline $\mathrm{C} 50 / 60$ & $142.00 \mathrm{~m}^{3}$ & Road Train & 20 & 50 & 180 & $34.08 *$ & $61,344.00 \mathrm{tkm}$ \\
\hline $\mathrm{C} 25 / 30$ & $59.00 \mathrm{~m}^{3}$ & Truck & 16 & 50 & 16.3 & 17.3 & $2255.92 \mathrm{tkm}+14.32 \mathrm{~kg}$ Diesel \\
\hline Epoxy resin & $0.56 \mathrm{t}$ & Van & 2 & 6 & 30 & 5 & $18.00 \mathrm{tkm}$ \\
\hline Quartz sand & $0.84 \mathrm{t}$ & $\begin{array}{l}\text { Small } \\
\text { Truck }\end{array}$ & 2 & 5 & 30 & 9.3 & $27.90 \mathrm{tkm}$ \\
\hline $\begin{array}{l}\text { Bituminous } \\
\text { sheeting }\end{array}$ & $3.09 \mathrm{t}$ & Van & 2 & 30 & 30 & 5 & $90.00 \mathrm{tkm}$ \\
\hline Mastic asphalt & $56.45 \mathrm{t}$ & Road Train & 4 & 50 & 30 & 27 & $\begin{array}{c}1620.00 \mathrm{tkm}+6.10 \mathrm{~kg} \text { Diesel } \\
+2.65 \mathrm{~kg} \text { heating oil }\end{array}$ \\
\hline Joint sealant & $0.17 \mathrm{t}$ & Van & 2 & 2 & 30 & 5 & $5.10 \mathrm{tkm}$ \\
\hline $\begin{array}{l}\text { Spreading } \\
\text { material }\end{array}$ & $1.95 \mathrm{t}$ & $\begin{array}{l}\text { Small } \\
\text { Truck }\end{array}$ & 2 & 10 & 30 & 9.3 & $55.80 \mathrm{tkm}$ \\
\hline \multirow{2}{*}{ Steel } & \multirow{2}{*}{$68.00 \mathrm{t}$} & \multirow{2}{*}{ Road Train } & 4 & 50 & 150 & 27 & \multirow{2}{*}{10125 tkm } \\
\hline & & & 2 & 25 & 150 & 27 & \\
\hline
\end{tabular}

Table A16. Life cycle inventory of the transport of CC bridge design, using GaBi database.

\begin{tabular}{|c|c|c|c|}
\hline Medium & Quantity & Unit & Delivery Process \\
\hline Diesel & 59.80 & $\mathrm{~kg}$ & $\begin{array}{l}\text { Diesel mix at filling station, consumption mix, at filling station, } \\
\text { from crude oil and bio components, } 8.37 \mathrm{wt} . \% \text { bio components, DE }\end{array}$ \\
\hline Light fuel oil & 2.65 & $\mathrm{~kg}$ & $\begin{array}{l}\text { Light fuel oil at refinery (EN15804 B6), production mix, at refinery, } \\
\text { from crude oil, } 0.1 \mathrm{wt} \% \text { sulphur, DE }\end{array}$ \\
\hline $\begin{array}{l}\text { Transporting } \\
\text { capacity }\end{array}$ & 113.10 & $\mathrm{tkm}$ & $\begin{array}{l}\text { Delivery van (EN15804 A4), production mix, at plant, technology } \\
\text { mix, diesel driven, cargo, DE }\end{array}$ \\
\hline $\begin{array}{l}\text { Transporting } \\
\text { capacity }\end{array}$ & 83.70 & $\mathrm{tkm}$ & $\begin{array}{l}\text { Small truck (EN15804 A4), production mix, at plant, technology } \\
\text { mix, DE }\end{array}$ \\
\hline $\begin{array}{l}\text { Transporting } \\
\text { capacity }\end{array}$ & 8234.11 & $\mathrm{tkm}$ & Truck (EN15804 A4), production mix, at plant, technology mix, DE \\
\hline $\begin{array}{l}\text { Transporting } \\
\text { capacity }\end{array}$ & $73,089.00$ & $\mathrm{tkm}$ & $\begin{array}{l}\text { Road train (EN15804 A4), production mix, at plant, } \\
\text { technology mix, DE }\end{array}$ \\
\hline
\end{tabular}

Table A17. Transport details of UHPC bridge design.

\begin{tabular}{|c|c|c|c|c|c|c|c|}
\hline Material & Quantity & $\begin{array}{l}\text { Transport } \\
\text { Medium }\end{array}$ & $\begin{array}{c}\text { Rides } \\
\text { (Quantity) }\end{array}$ & $\begin{array}{c}\text { Workload } \\
(\%)\end{array}$ & $\begin{array}{c}\text { Distance } \\
(\mathbf{k m})\end{array}$ & $\begin{array}{c}\text { Payload } \\
(t)\end{array}$ & Transport Capacity \\
\hline \multirow{2}{*}{$\mathrm{C} 35 / 45$} & \multirow{2}{*}{$25.00 \mathrm{~m}^{3}$} & \multirow{2}{*}{ Truck } & 6 & 50 & 16.3 & 17.3 & \multirow{2}{*}{$930.57 \mathrm{tkm}+7.16 \mathrm{~kg}$ Diesel } \\
\hline & & & 2 & 15 & 16.3 & 17.3 & \\
\hline $\mathrm{C} 50 / 60$ & $180.00 \mathrm{~m}^{3}$ & Road Train & 20 & 50 & 180 & $43.2 *$ & $77,760.00 \mathrm{tkm}$ \\
\hline \multirow{2}{*}{ M3Q+ } & \multirow{2}{*}{$27.50 \mathrm{~m}^{3}$} & \multirow{2}{*}{ Truck } & 6 & 50 & 16.3 & 17.3 & \multirow{2}{*}{$1015.16 \mathrm{tkm}+7.16 \mathrm{~kg}$ Diesel } \\
\hline & & & 2 & 30 & 16.3 & 17.3 & \\
\hline \multirow{2}{*}{ M2Q } & $1.1 \mathrm{~m}^{3}$ & Truck & 2 & 10 & 16.3 & 17.3 & $56.40 \mathrm{tkm}+1.79 \mathrm{~kg}$ diesel \\
\hline & $33.00 \mathrm{~m}^{3}$ & Road Train & 6 & 50 & 180 & 27 & $14,580.00 \mathrm{tkm}$ \\
\hline $\begin{array}{l}\text { Polyurethane } \\
\text { cement }\end{array}$ & $0.12 \mathrm{t}$ & Van & 2 & 1 & 30 & 5 & $3.00 \mathrm{tkm}$ \\
\hline Mastic asphalt & $1.73 \mathrm{t}$ & $\begin{array}{l}\text { Small } \\
\text { Truck }\end{array}$ & 2 & 10 & 30 & 9.3 & $\begin{array}{c}55.80 \mathrm{tkm}+3.04 \mathrm{~kg} \text { diesel }+ \\
1.33 \mathrm{~kg} \text { heating oil }\end{array}$ \\
\hline Sma & 28.80 & Road Train & 2 & 50 & 30 & 27 & $810.00 \mathrm{tkm}$ \\
\hline Joint sealant & $0.10 \mathrm{t}$ & Van & 2 & 1 & 30 & 5 & $3.00 \mathrm{tkm}$ \\
\hline
\end{tabular}


Table A17. Cont.

\begin{tabular}{|c|c|c|c|c|c|c|c|}
\hline \multirow{2}{*}{ Material } & \multirow{2}{*}{ Quantity } & \multirow{2}{*}{$\begin{array}{l}\text { Transport } \\
\text { Medium }\end{array}$} & \multirow{2}{*}{$\begin{array}{c}\text { Rides } \\
\text { (Quantity) }\end{array}$} & \multirow{2}{*}{$\begin{array}{c}\text { Workload } \\
(\%)\end{array}$} & \multirow{2}{*}{$\begin{array}{c}\text { Distance } \\
(\mathbf{k m})\end{array}$} & \multirow{2}{*}{$\begin{array}{c}\text { Payload } \\
(t)\end{array}$} & \multirow{2}{*}{ Transport Capacity } \\
\hline & & & & & & & \\
\hline $\begin{array}{l}\text { Spreading } \\
\text { material }\end{array}$ & $0.90 \mathrm{t}$ & $\begin{array}{l}\text { Small } \\
\text { Truck }\end{array}$ & 2 & 5 & 30 & 9.3 & $27.90 \mathrm{tkm}$ \\
\hline Epoxy resin & $1.86 \mathrm{t}$ & Van & 2 & 19 & 30 & 5 & $57.00 \mathrm{tkm}$ \\
\hline \multirow{2}{*}{ Steel } & \multirow{2}{*}{$61.90 \mathrm{t}$} & \multirow{2}{*}{ Road Train } & 4 & 50 & 150 & 27 & \multirow{2}{*}{$9315 \mathrm{tkm}$} \\
\hline & & & 2 & 15 & 150 & 27 & \\
\hline
\end{tabular}

$* 180.00 \mathrm{~m}^{3} \cdot 2.4 \mathrm{t} / \mathrm{m}^{3}=43.2 \mathrm{t}$.

Table A18. Life cycle inventory of the transport of UHPC bridge design using GaBi constructin material database.

\begin{tabular}{|c|c|c|c|}
\hline Medium & Quantity & Unit & Delivery Process \\
\hline Diesel & 19.15 & $\mathrm{~kg}$ & $\begin{array}{l}\text { Diesel mix at filling station, consumption mix, at filling station, from } \\
\text { crude oil and bio components, } 8.37 \text { wt. } \% \text { bio components, DE }\end{array}$ \\
\hline Light fuel oil & 1.33 & $\mathrm{~kg}$ & $\begin{array}{l}\text { Light fuel oil at refinery (EN15804 B6), production mix, at refinery, from } \\
\text { crude oil, } 0.1 \text { wt.\% sulphur, DE }\end{array}$ \\
\hline $\begin{array}{l}\text { Transporting } \\
\text { capacity }\end{array}$ & 63.00 & $\mathrm{tkm}$ & $\begin{array}{l}\text { Delivery van (EN15804 A4), production mix, at plant, technology mix, } \\
\text { diesel driven, cargo, DE }\end{array}$ \\
\hline $\begin{array}{l}\text { Transporting } \\
\text { capacity }\end{array}$ & 83.70 & $\mathrm{tkm}$ & $\begin{array}{l}\text { Small truck (EN15804 A4), production mix, at plant, } \\
\text { technology mix, DE }\end{array}$ \\
\hline $\begin{array}{l}\text { Transporting } \\
\text { capacity }\end{array}$ & 2002.13 & $\mathrm{tkm}$ & Truck (EN15804 A4), production mix, at plant, technology mix, DE \\
\hline $\begin{array}{l}\text { Transporting } \\
\text { capacity }\end{array}$ & $102,465.00$ & $\mathrm{tkm}$ & Road train (EN15804 A4), production mix, at plant, technology mix, DE \\
\hline
\end{tabular}

\section{Appendix C.3. Life Cycle Inventory of A5 Life Cycle Stage}

Table A19. Calculation of the required fuels for the installation of the components, CC bridge design.

\begin{tabular}{|c|c|c|c|c|c|}
\hline Component & Construction Machine & $\begin{array}{c}\text { Specific } \\
\text { Consumption }\end{array}$ & Quantity & Needs & $\begin{array}{l}\text { Energy } \\
\text { Carriers }\end{array}$ \\
\hline Sealing layer & $\begin{array}{l}\text { Surface welding } \\
\text { installation device }\end{array}$ & $0.33 \mathrm{~kg} / \mathrm{m}^{2}$ & $612.70 \mathrm{~m}^{2}$ & $202.19 \mathrm{~kg}$ & Propane \\
\hline Cross member & $\begin{array}{l}\text { Truck concrete pump } \\
\text { Internal vibrator }\end{array}$ & $\begin{array}{l}0.39 \mathrm{~L} / \mathrm{m}^{3} \\
0.9 \mathrm{MJ} / \mathrm{m}^{3}\end{array}$ & $159.00 \mathrm{~m}^{3}$ & $\begin{array}{c}61.85 \mathrm{~L} \\
143.10 \mathrm{MJ}\end{array}$ & $\begin{array}{c}\text { Diesel } \\
\text { Electricity }\end{array}$ \\
\hline Side member & Crane & $19.2 \mathrm{MJ} / \mathrm{m}^{3}$ & $142.00 \mathrm{~m}^{3}$ & $2726.40 \mathrm{MJ}$ & Electricity \\
\hline Topping & $\begin{array}{c}\text { Cooker } \\
\text { Plank } \\
\text { Potting stove } \\
\text { Rubber wheeled roller } \\
\text { Smooth roller }\end{array}$ & $\begin{array}{l}8.00 \mathrm{~L} / \mathrm{h} \\
3.50 \mathrm{~L} / \mathrm{h} \\
5.00 \mathrm{~L} / \mathrm{h} \\
0.60 \mathrm{~kg} / \mathrm{h} \\
8.00 \mathrm{~L} / \mathrm{h} \\
8.00 \mathrm{~L} / \mathrm{h}\end{array}$ & $\begin{array}{l}0.40 \mathrm{~h} \\
7.70 \mathrm{~h} \\
0.09 \mathrm{~h} \\
0.11 \mathrm{~h}\end{array}$ & $\begin{array}{l}3.20 \mathrm{~L} \\
1.40 \mathrm{~L} \\
2.00 \mathrm{~L} \\
4.62 \mathrm{~kg} \\
0.72 \mathrm{~L} \\
0.88 \mathrm{~L}\end{array}$ & $\begin{array}{c}\text { Diesel } \\
\text { Fuel oil } \\
\text { Diesel } \\
\text { Propane } \\
\text { Diesel } \\
\text { Diesel }\end{array}$ \\
\hline Road caps & $\begin{array}{l}\text { Truck concrete pump } \\
\text { Internal vibrator }\end{array}$ & $\begin{array}{l}0.39 \mathrm{~L} / \mathrm{m}^{3} \\
0.9 \mathrm{MJ} / \mathrm{m}^{3}\end{array}$ & $59.00 \mathrm{~m}^{3}$ & $\begin{array}{c}22.95 \mathrm{~L} \\
53.10 \mathrm{MJ}\end{array}$ & $\begin{array}{c}\text { Diesel } \\
\text { Electricity }\end{array}$ \\
\hline Steel & Crane & $8 \mathrm{MJ} / \mathrm{t}$ & $68.00 \mathrm{t}$ & $544.00 \mathrm{MJ}$ & Electricity \\
\hline
\end{tabular}

Table A20. Life cycle inventory of A5 life cycle stage of the CC bridge design, using GaBi construction materials database.

\begin{tabular}{|c|c|c|c|}
\hline Medium & Quantity & Unit & Delivery Process \\
\hline Diesel & 77.40 & $\mathrm{~kg}$ & $\begin{array}{l}\text { Diesel mix at filling station, consumption mix, at filling station, } \\
\text { from crude oil and bio components, } 8.37 \text { wt. \% bio components, DE }\end{array}$ \\
\hline Electricity & 3466.60 & MJ & $\begin{array}{l}\text { Electricity grid mix } 1 \mathrm{kV}-60 \mathrm{kV} \text {, consumption mix, to consumer, } \mathrm{AC} \text {, } \\
\text { technology mix, } 1 \mathrm{kV}-60 \mathrm{kV}, \mathrm{DE}\end{array}$ \\
\hline Light fuel oil & 1.18 & $\mathrm{~kg}$ & $\begin{array}{l}\text { Light fuel oil at refinery (EN15804 B6), production mix, at refinery, } \\
\text { from crude oil, } 0.1 \text { wt.\% sulphur, DE }\end{array}$ \\
\hline $\begin{array}{l}\text { Liquefied } \\
\text { petroleum gas }\end{array}$ & 206.81 & $\mathrm{~kg}$ & $\begin{array}{l}\text { Liquefied Petroleum Gas (LPG) (EN15804 B6), production mix, } \\
\text { at refinery, Mix of } 70 \% \text { propane and } 30 \% \text { butane, DE }\end{array}$ \\
\hline
\end{tabular}


Table A21. Calculation of the required fuels for the installation of the components, UHPC bridge design.

\begin{tabular}{|c|c|c|c|c|c|}
\hline Component & Construction Machine & $\begin{array}{c}\text { Specific } \\
\text { Consumption }\end{array}$ & Quantity & Need & $\begin{array}{l}\text { Energy } \\
\text { Carriers }\end{array}$ \\
\hline Cross member & $\begin{array}{l}\text { Truck concrete pump } \\
\text { Internal vibrator }\end{array}$ & $\begin{array}{l}0.39 \mathrm{~L} / \mathrm{m}^{3} \\
0.9 \mathrm{MJ} / \mathrm{m}^{3}\end{array}$ & $25.00 \mathrm{~m}^{3}$ & $\begin{array}{c}9.73 \mathrm{~L} \\
22.50 \mathrm{MJ}\end{array}$ & $\begin{array}{c}\text { Diesel } \\
\text { Electricity }\end{array}$ \\
\hline Side member & $\begin{array}{c}\text { Crane } \\
\text { Truck concrete pump } \\
\text { Internal vibrator }\end{array}$ & $\begin{array}{c}19.2 \mathrm{MJ} / \mathrm{m}^{3} \\
0.39 \mathrm{~L} / \mathrm{m}^{3} \\
0.9 \mathrm{MJ} / \mathrm{m}^{3}\end{array}$ & $\begin{array}{l}180.00 \mathrm{~m}^{3} \\
27.50 \mathrm{~m}^{3}\end{array}$ & $\begin{array}{c}3456.00 \mathrm{MJ} \\
10.70 \mathrm{~L} \\
24.75 \mathrm{MJ}\end{array}$ & $\begin{array}{l}\text { Electricity } \\
\text { Diesel } \\
\text { Electricity }\end{array}$ \\
\hline Concrete Joints & $\begin{array}{l}\text { Truck concrete pump } \\
\text { Internal vibrator }\end{array}$ & $\begin{array}{l}0.39 \mathrm{~L} / \mathrm{m}^{3} \\
0.9 \mathrm{MJ} / \mathrm{m}^{3}\end{array}$ & $1.1 \mathrm{~m}^{3}$ & $\begin{array}{c}0.43 \mathrm{~L} \\
0.99 \mathrm{MJ}\end{array}$ & $\begin{array}{c}\text { Diesel } \\
\text { Electricity }\end{array}$ \\
\hline Topping & $\begin{array}{c}\text { Cooker } \\
\text { Finisher } \\
\text { Potting stove } \\
\text { Roller }\end{array}$ & $\begin{array}{c}8.00 \mathrm{~L} / \mathrm{h} \\
3.50 \mathrm{~L} / \mathrm{h} \\
8.5 \mathrm{~L} / \mathrm{h} \\
0.6 \mathrm{~kg} / \mathrm{h} \\
6.00 \mathrm{~L} / \mathrm{h}\end{array}$ & $\begin{array}{l}0.33 \mathrm{~h} \\
0.18 \mathrm{~h} \\
4.40 \mathrm{~h} \\
0.18 \mathrm{~h}\end{array}$ & $\begin{array}{c}2.64 \mathrm{~L} \\
1.16 \mathrm{~L} \\
1.53 \mathrm{~L} \\
2.64 \mathrm{~kg} \\
1.08 \mathrm{~L}\end{array}$ & $\begin{array}{c}\text { Diesel } \\
\text { Heating oil } \\
\text { Diesel } \\
\text { Propane } \\
\text { Diesel }\end{array}$ \\
\hline Steel & Crane & $8 \mathrm{MJ} / \mathrm{t}$ & $61.90 \mathrm{t}$ & $495.20 \mathrm{MJ}$ & Electricity \\
\hline
\end{tabular}

Table A22. Life cycle inventory of A5 life cycle stage of the UHPC bridge design, using GaBi construction materials database.

\begin{tabular}{cccl}
\hline Medium & Quantity & Unit & \multicolumn{1}{c}{ Delivery Process } \\
\hline Diesel & 22.05 & $\mathrm{~kg}$ & $\begin{array}{l}\text { Diesel mix at filling station, consumption mix, at filling station, from } \\
\text { crude oil and bio components, 8.37 wt.\% bio components, DE }\end{array}$ \\
Electricity & 4633.04 & $\mathrm{MJ}$ & $\begin{array}{l}\text { Electricity grid mix } 1 \mathrm{kV}-60 \mathrm{kV}, \text { consumption mix, to consumer, AC, } \\
\text { technology mix, } 1 \mathrm{kV}-60 \mathrm{kV}, \mathrm{DE}\end{array}$ \\
$\begin{array}{c}\text { Light fuel oil } \\
\text { Liquefied }\end{array}$ & 0.97 & $\mathrm{~kg}$ & $\begin{array}{l}\text { Light fuel oil at refinery (EN15804 B6), production mix, at refinery, from } \\
\text { crude oil, 0.1 wt.\% sulphur, DE } \\
\text { Liquefied Petroleum Gas (LPG) (EN15804 B6), production mix, at } \\
\text { refinery, Mix of 70\% propane and 30\% butane, DE }\end{array}$ \\
\hline
\end{tabular}

\section{Appendix C.4. Life Cycle Inventory for B Life Cycle Stage}

Table A23. Calculation of the required fuels for the replacement of the lining and sealing, B4 life cycle stage, CC bridge design.

\begin{tabular}{|c|c|c|c|c|c|}
\hline Task & Construction Machine & $\begin{array}{c}\text { Specific } \\
\text { Consumption }\end{array}$ & Quantity & Need & $\begin{array}{l}\text { Energy } \\
\text { Carriers }\end{array}$ \\
\hline \multirow{3}{*}{ Removal } & Milling machine & $2.54 \mathrm{~L} / \mathrm{m}^{3}$ & $23.67 \mathrm{~m}^{3}$ & $60.12 \mathrm{~L}$ & Diesel \\
\hline & Excavator with peeling & $0.2 \mathrm{~L} / \mathrm{m}^{2}$ & & $122.54 \mathrm{~L}$ & Diesel \\
\hline & device & $0.13 \mathrm{~L} / \mathrm{m}^{2}$ & $612.70 \mathrm{~m}^{2}$ & $79.65 \mathrm{~L}$ & Propane \\
\hline \multirow{2}{*}{ Editing } & \multirow{2}{*}{ Treatment facility } & $13.00 \mathrm{MJ} / \mathrm{t}$ & \multirow{2}{*}{$63.06 \mathrm{t}$} & $819.78 \mathrm{MJ}$ & Diesel \\
\hline & & $10.00 \mathrm{MJ} / \mathrm{t}$ & & $630.60 \mathrm{MJ}$ & Electricity \\
\hline \multirow{6}{*}{ Renewal } & $\begin{array}{l}\text { Surface welding } \\
\text { installation device }\end{array}$ & 0.33 & 612.70 & $202.19 \mathrm{~kg}$ & Propane \\
\hline & Cooker + plank & 13.00 & 0.40 & $5.20 \mathrm{~L}$ & Diesel \\
\hline & Cooker & 3.50 & 0.40 & $1.40 \mathrm{~L}$ & Heating oil \\
\hline & Potting stove & 0.60 & 7.70 & $4.62 \mathrm{~kg}$ & Propane \\
\hline & Rubber wheeled roller & 8.00 & 0.09 & $0.72 \mathrm{~L}$ & Diesel \\
\hline & Smooth roller & 8.00 & 0.11 & $0.88 \mathrm{~L}$ & Diesel \\
\hline
\end{tabular}

Table A24. Calculation of the required transports when replacing the pavement and sealing, B4 life cycle stage, CC bridge design.

\begin{tabular}{cccccccc}
\hline \multirow{2}{*}{ Material } & \multirow{2}{*}{ Quantity } & $\begin{array}{c}\text { Means of } \\
\text { Transport }\end{array}$ & Rides & Workload & Distance & Payload & \multirow{2}{*}{ Transport Capacity } \\
\cline { 4 - 6 } & & & (Quantity) & $\mathbf{( \% )}$ & $\mathbf{( k m )}$ & $\mathbf{( t )}$ & \\
\hline \multirow{3}{*}{ Covering + sealing } & \multirow{2}{*}{$63.06 \mathrm{t}$} & \multirow{2}{*}{ Road Train } & 4 & 50 & 30 & 27 & $1863.00 \mathrm{tkm}$ \\
\hline
\end{tabular}


Table A24. Cont

\begin{tabular}{|c|c|c|c|c|c|c|c|}
\hline \multirow{2}{*}{ Material } & \multirow{2}{*}{ Quantity } & \multirow{2}{*}{$\begin{array}{l}\text { Means of } \\
\text { Transport }\end{array}$} & \multirow{2}{*}{$\begin{array}{c}\text { Rides } \\
\text { (Quantity) }\end{array}$} & \multirow{2}{*}{$\begin{array}{c}\text { Workload } \\
(\%)\end{array}$} & \multirow{2}{*}{$\begin{array}{c}\text { Distance } \\
(\mathbf{k m})\end{array}$} & \multirow{2}{*}{$\begin{array}{c}\text { Payload } \\
\text { (t) }\end{array}$} & \multirow{2}{*}{ Transport Capacity } \\
\hline & & & & & & & \\
\hline \multicolumn{8}{|c|}{ Delivery transport } \\
\hline Epoxy resin & $0.56 \mathrm{t}$ & Van & 2 & 6 & 30 & 5 & $18.00 \mathrm{t} \mathrm{km}$ \\
\hline Quartz sand & $0.84 \mathrm{t}$ & $\begin{array}{l}\text { Small } \\
\text { Truck }\end{array}$ & 2 & 5 & 30 & 9.3 & $27.90 \mathrm{t} \mathrm{km}$ \\
\hline $\begin{array}{l}\text { Bituminous } \\
\text { sheeting }\end{array}$ & $3.09 \mathrm{t}$ & Van & 2 & 30 & 30 & 5 & $90.00 \mathrm{t} \mathrm{km}$ \\
\hline Mastic asphalt & $56.45 \mathrm{t}$ & Road Train & 4 & 50 & 30 & 27 & $\begin{array}{c}1620.00 \mathrm{t} \mathrm{km} \mathrm{+} \\
6.10 \mathrm{~kg} \text { Diesel + } \\
2.65 \mathrm{~kg} \text { heating oil }\end{array}$ \\
\hline Joint sealant & $0.17 \mathrm{t}$ & Van & 2 & 2 & 30 & 5 & $5.10 \mathrm{t} \mathrm{km}$ \\
\hline Spreading material & $1.95 \mathrm{t}$ & $\begin{array}{l}\text { Small } \\
\text { Truck }\end{array}$ & 2 & 10 & 30 & 9.3 & $55.80 \mathrm{t} \mathrm{km}$ \\
\hline
\end{tabular}

Table A25. Life cycle inventory of B4 life cycle stage of the CC bridge design using GaBi construction materials database.

\begin{tabular}{|c|c|c|c|}
\hline Material & Quantity & Unit & Delivery Process \\
\hline Bitumen & 169.54 & $\mathrm{~kg}$ & Bitumen at refinery, production mix, at refinery, from crude oil, DE \\
\hline Bitumen sheets & 3064.36 & $\mathrm{~kg}$ & $\begin{array}{l}\text { Bitumen sheets PYE-PV } 200 \text { S5 (not slated) }(\mathrm{EN} 15804 \mathrm{~A} 1-\mathrm{A} 3) \text {, } \\
\text { production mix, at plant, technology mix, } 5.2 \mathrm{~kg} / \mathrm{m}^{2}, \mathrm{DE}\end{array}$ \\
\hline Bitumen sheets & 30.42 & $\mathrm{~kg}$ & $\begin{array}{l}\text { Bitumen sheet v } 60 \text { (EN15804 A1-A3), production mix, at plant, } \\
\text { technology mix, } 5 \mathrm{~kg} / \mathrm{m}^{2}, \mathrm{DE}\end{array}$ \\
\hline Epoxy resin & 562.00 & $\mathrm{~kg}$ & $\begin{array}{l}\text { Epoxy Resin (EP) Mix, consumption mix, to consumer, from } \\
\text { Bisphenol A and epichlorohydrin, approx. } 1.15 \mathrm{~g} / \mathrm{cm}^{3}, \mathrm{DE}\end{array}$ \\
\hline $\begin{array}{l}\text { Quartz sand } \\
(0 / 2)\end{array}$ & 843.00 & $\mathrm{~kg}$ & $\begin{array}{l}\text { Silica sand (Excavation and processing), production mix, at plant, } \\
\text { technology mix, sand, diameter }<2 \mathrm{~mm}, \mathrm{DE}\end{array}$ \\
\hline Diesel & 188.52 & $\mathrm{~kg}$ & $\begin{array}{l}\text { Diesel mix at filling station, consumption mix, at filling station, } \\
\text { from crude oil and bio components, } 8.37 \mathrm{wt} . \% \text { bio components, } \mathrm{DE}\end{array}$ \\
\hline Electricity & 630.60 & MJ & $\begin{array}{l}\text { Electricity grid mix } 1 \mathrm{kV}-60 \mathrm{kV} \text {, consumption mix, to consumer, } \mathrm{AC} \text {, } \\
\text { technology mix, } 1 \mathrm{kV}-60 \mathrm{kV}, \mathrm{DE}\end{array}$ \\
\hline Light fuel oil & 5.16 & $\mathrm{~kg}$ & $\begin{array}{l}\text { Light fuel oil at refinery (EN15804 B6), production mix, at refinery, } \\
\text { from crude oil, } 0.1 \text { wt.\% sulphur, DE }\end{array}$ \\
\hline $\begin{array}{l}\text { Liquefied } \\
\text { petroleum gas }\end{array}$ & 206.97 & $\mathrm{~kg}$ & $\begin{array}{l}\text { Liquefied Petroleum Gas (LPG) (EN15804 B6), production mix, at } \\
\text { refinery, Mix of } 70 \% \text { propane and 30\% butane, DE }\end{array}$ \\
\hline Melted asphalt & 56.45 & $\mathrm{t}$ & $\begin{array}{l}\text { Mastic asphalt (EN15804 A1-A3), production mix, at plant, } \\
\text { technology mix, } 2400 \mathrm{~kg} / \mathrm{m}^{3}, \mathrm{DE}\end{array}$ \\
\hline Split (2/15) & 1950.00 & $\mathrm{~kg}$ & $\begin{array}{l}\text { Crushed stone grain 2-15 mm (EN15804 A1-A3), production mix, at } \\
\text { plant, technology mix, dried, DE }\end{array}$ \\
\hline $\begin{array}{l}\text { Transporting } \\
\text { capacity }\end{array}$ & 113.10 & $\mathrm{tkm}$ & $\begin{array}{l}\text { Delivery van (EN15804 A4), production mix, at plant, technology } \\
\text { mix, diesel driven, cargo, DE }\end{array}$ \\
\hline $\begin{array}{l}\text { Transporting } \\
\text { capacity }\end{array}$ & 83.70 & $\mathrm{tkm}$ & $\begin{array}{l}\text { Small truck (EN15804 A4), production mix, at plant, technology } \\
\text { mix, DE }\end{array}$ \\
\hline $\begin{array}{l}\text { Transporting } \\
\text { capacity }\end{array}$ & 3483.00 & $\mathrm{tkm}$ & $\begin{array}{l}\text { Road train (EN15804 A4), production mix, at plant, technology mix, } \\
\text { DE }\end{array}$ \\
\hline
\end{tabular}

Table A26. Calculation of the required fuels when replacing the caps and parts of the concrete surface, module B4, CC bridge design.

\begin{tabular}{|c|c|c|c|c|c|}
\hline Task & Construction Machine & $\begin{array}{c}\text { Specific } \\
\text { Consumption }\end{array}$ & Quantity & Needs & $\begin{array}{l}\text { Energy } \\
\text { Carriers }\end{array}$ \\
\hline \multirow[b]{2}{*}{ Removal } & $\begin{array}{l}\text { Hydraulic hammer, steel } \\
\text { cutting + loading }\end{array}$ & $17.60 \mathrm{~L} / \mathrm{m}^{3}$ & $59.00 \mathrm{~m}^{3}$ & $1038.40 \mathrm{~L}$ & Diesel \\
\hline & $\begin{array}{c}\text { Pneumatic hammer } \\
\text { Sandblasting }\end{array}$ & $\begin{array}{l}0.43 \mathrm{~L} / \mathrm{m}^{2} \\
0.48 \mathrm{~L} / \mathrm{m}^{2}\end{array}$ & $108.18 \mathrm{~m}^{2}$ & $\begin{array}{l}46.52 \mathrm{~L} \\
51.93 \mathrm{~L}\end{array}$ & $\begin{array}{l}\text { Diesel } \\
\text { Diesel }\end{array}$ \\
\hline
\end{tabular}


Table A26. Cont.

\begin{tabular}{cccccc}
\hline Task & Construction Machine & $\begin{array}{c}\text { Specific } \\
\text { Consumption }\end{array}$ & Quantity & Needs & $\begin{array}{c}\text { Energy } \\
\text { Carriers }\end{array}$ \\
\hline \multirow{4}{*}{ Editing } & Dredgers & $0.30 \mathrm{~L} / \mathrm{m}^{3}$ & & $19.00 \mathrm{~L}$ & Diesel \\
& Wheel loader & $0.60 \mathrm{~L} / \mathrm{m}^{3}$ & $63.33 \mathrm{~m}^{3}$ & $38.00 \mathrm{~L}$ & $\begin{array}{c}\text { Diesel } \\
\text { Treatment facility }\end{array}$ \\
& $18.26 \mathrm{MJ} / \mathrm{m}^{3}$ & & $1156.35 \mathrm{MJ}$ & Electricity \\
& Treatment facility & $13.00 \mathrm{MJ} / \mathrm{t}$ & \multirow{2}{*}{$8.00 \mathrm{t}$} & $104.00 \mathrm{MJ}$ & Diesel \\
& $10.00 \mathrm{MJ} / \mathrm{t}$ & & $80.00 \mathrm{MJ}$ & Electricity \\
\hline \multirow{3}{*}{ Renew } & Truck concrete pump & $0.39 \mathrm{~L} / \mathrm{m}^{3}$ & & $22.95 \mathrm{~L}$ & Diesel \\
& Internal vibrator & $0.90 \mathrm{MJ} / \mathrm{m}^{3}$ & $59.00 \mathrm{~m}^{3}$ & $53.10 \mathrm{MJ}$ & Electricity \\
& Shotcrete & $0.40 \mathrm{~L} / \mathrm{m}^{2}$ & & $43.27 \mathrm{~L}$ & Diesel \\
& Crane & $8.00 \mathrm{MJ} / \mathrm{t}$ & $8.00 \mathrm{t}$ & $64.00 \mathrm{MJ}$ & Electricity \\
\hline
\end{tabular}

Table A27. Calculation of the required transports when replacing the caps and parts of the concrete surface, module B4, CC bridge design.

\begin{tabular}{|c|c|c|c|c|c|c|c|}
\hline \multirow{2}{*}{ Material } & \multirow{2}{*}{ Quantity } & \multirow{2}{*}{$\begin{array}{l}\text { Means of } \\
\text { Transport }\end{array}$} & \multirow{2}{*}{$\begin{array}{c}\text { Rides } \\
\text { (Quantity) }\end{array}$} & \multirow{2}{*}{$\begin{array}{c}\text { Workload } \\
(\%)\end{array}$} & \multirow{2}{*}{$\begin{array}{c}\text { Distance } \\
(\mathbf{k m})\end{array}$} & \multirow{2}{*}{$\begin{array}{c}\text { Payload } \\
(t)\end{array}$} & \multirow{2}{*}{ Transport Capacity } \\
\hline & & & & & & & \\
\hline \multicolumn{8}{|c|}{ Outward transport } \\
\hline Concrete & & & 10 & 50 & 30 & 27 & \\
\hline fracture & $152 \mathrm{t}$ & Road Irain & 2 & 30 & 30 & 27 & $4536.00 \mathrm{tkm}$ \\
\hline Steel & $8.00 \mathrm{t}$ & $\begin{array}{l}\text { Small } \\
\text { Truck }\end{array}$ & 2 & 43 & 150.00 & 9.30 & $1199.70 \mathrm{tkm}$ \\
\hline \multicolumn{8}{|c|}{ Delivery transport } \\
\hline $\mathrm{C} 25 / 30$ & $59.00 \mathrm{~m}^{3}$ & Truck & 16 & 50 & 16.30 & 17.30 & $\begin{array}{c}2255.92 \mathrm{tkm}+ \\
14.32 \mathrm{~kg} \text { Diesel }\end{array}$ \\
\hline Steel & $8.00 \mathrm{t}$ & $\begin{array}{l}\text { Small } \\
\text { Truck }\end{array}$ & 2 & 43 & 150.00 & 9.30 & $1199.70 \mathrm{tkm}$ \\
\hline Shotcrete & $4.33 \mathrm{~m}^{3}$ & Truck & 2 & 30 & 16.30 & 17.30 & $\begin{array}{c}169.19+1.79 \mathrm{~kg} \\
\text { Diesel }\end{array}$ \\
\hline
\end{tabular}

Table A28. Life cycle inventory for B4 life cycle stage of the CC bridge design using GaBi construction materials database.

\begin{tabular}{cccl}
\hline Material & Quantity & Unit & \multicolumn{1}{c}{ Delivery Process } \\
\hline C25/30, A1-A3 & 59.00 & $\mathrm{~m}^{3}$ & C25/30. A1-A3 \\
\hline C35/45, A1-A3 & 4.33 & $\mathrm{~m}^{3}$ & C35/45, A1-A3 \\
\hline Steel wire & 8.00 & $\mathrm{t}$ & $\begin{array}{l}\text { Reinforced steel (wire) (EN15804 A1-A3), production mix, } \\
\text { at plant, EAF route, wire, DE }\end{array}$ \\
\hline $\begin{array}{c}\text { Diesel } \\
\text { Electricity }\end{array}$ & 1083.31 & $\mathrm{~kg}$ & $\begin{array}{l}\text { Diesel mix at filling station, consumption mix, at filling } \\
\text { station, from crude oil and bio components, 8.37 wt. } \% \text { bio } \\
\text { components, DE }\end{array}$ \\
\hline $\begin{array}{c}\text { Transporting } \\
\text { capacity }\end{array}$ & 2425.11 & $\mathrm{MJ}$ & $\begin{array}{l}\text { Electricity grid mix 1 kV-60 kV, consumption mix, to } \\
\text { consumer, AC, technology mix, 1 kV-60 kV, DE }\end{array}$ \\
\hline $\begin{array}{c}\text { Transporting } \\
\text { capacity }\end{array}$ & 4536.00 & $\begin{array}{l}\text { Truck (EN15804 A4), production mix, at plant, technology mix, } \\
\text { DE }\end{array}$ \\
\hline $\begin{array}{c}\text { Transporting } \\
\text { capacity }\end{array}$ & 2399.40 & $\begin{array}{l}\text { Road train (EN15804 A4), production mix, at plant, } \\
\text { technology mix, DE }\end{array}$ \\
\hline
\end{tabular}


Table A29. Calculation of the required fuels when replacing the pavement, module B4, UHPC bridge design.

\begin{tabular}{|c|c|c|c|c|c|}
\hline Task & $\begin{array}{c}\text { Construction } \\
\text { Machine }\end{array}$ & $\begin{array}{c}\text { Specific } \\
\text { Consumption }\end{array}$ & Quantity & Needs & Energy Carrier \\
\hline Removal & Milling machine & $2.54 \mathrm{~L} / \mathrm{m}^{3}$ & $12.81 \mathrm{~m}^{3}$ & $32.54 \mathrm{~L}$ & Diesel \\
\hline Editing & Treatment facility & $\begin{array}{l}13.00 \mathrm{MJ} / \mathrm{t} \\
10.00 \mathrm{MJ} / \mathrm{t}\end{array}$ & $31.52 \mathrm{t}$ & $\begin{array}{l}\text { 409.76 MJ } \\
\text { 315.20 MJ }\end{array}$ & $\begin{array}{c}\text { Diesel } \\
\text { Electricity }\end{array}$ \\
\hline Renew & $\begin{array}{c}\text { Cooker } \\
\text { Finisher } \\
\text { Potting stove } \\
\text { Roller }\end{array}$ & $\begin{array}{c}8.00 \mathrm{~L} / \mathrm{h} \\
3.50 \mathrm{~L} / \mathrm{h} \\
8.50 \mathrm{~L} / \mathrm{h} \\
0.60 \mathrm{~kg} / \mathrm{h} \\
6.00 \mathrm{~L} / \mathrm{h}\end{array}$ & $\begin{array}{l}0.33 \mathrm{~h} \\
0.18 \mathrm{~h} \\
4.40 \mathrm{~h} \\
0.18 \mathrm{~h}\end{array}$ & $\begin{array}{c}2.64 \mathrm{~L} \\
1.16 \mathrm{~L} \\
1.53 \mathrm{~L} \\
2.64 \mathrm{~kg} \\
1.081\end{array}$ & $\begin{array}{c}\text { Diesel } \\
\text { Heating oil } \\
\text { Diesel } \\
\text { Propane } \\
\text { Diesel }\end{array}$ \\
\hline
\end{tabular}

Table A30. Calculation of the required transports when replacing the surface, module B4, UHPC bridge design.

\begin{tabular}{|c|c|c|c|c|c|c|c|}
\hline \multirow{2}{*}{ Material } & \multirow{2}{*}{ Quantity } & \multirow{2}{*}{$\begin{array}{c}\text { Mean of } \\
\text { Transportation }\end{array}$} & Rides & Workload & Distance & Payload & \multirow{2}{*}{ Transport Capacity } \\
\hline & & & (Quantity) & $(\%)$ & $(\mathrm{km})$ & (t) & \\
\hline \multicolumn{8}{|c|}{ Outward transport } \\
\hline \multirow{2}{*}{ Topping } & \multirow[b]{2}{*}{$31.52 \mathrm{t}$} & \multirow{2}{*}{ Road Train } & 2 & 50 & 30 & 27 & \multirow[b]{2}{*}{$972.00 \mathrm{tkm}$} \\
\hline & & & 2 & 10 & 30 & 27 & \\
\hline \multicolumn{8}{|c|}{ Delivery transport } \\
\hline & & & & & & & $55.80 \mathrm{tkm}+3.04 \mathrm{~kg}$ \\
\hline Mastic asphalt & $1.73 \mathrm{t}$ & Small Truck & 2 & 10 & 30 & 9,3 & $\begin{array}{c}\text { Diesel }+1.33 \mathrm{~kg} \\
\text { heating oil }\end{array}$ \\
\hline SMA & $28.80 \mathrm{t}$ & Road Train & 2 & 50 & 30 & 27 & $810.00 \mathrm{tkm}$ \\
\hline Joint sealant & $0.10 \mathrm{t}$ & Van & 2 & 1 & 30 & 5 & $3.00 \mathrm{tkm}$ \\
\hline Spreading material & $0.90 \mathrm{t}$ & Small Truck & 2 & 5 & 30 & 27.90 & $27.90 \mathrm{tkm}$ \\
\hline
\end{tabular}

Table A31. Life cycle inventory of B4 life cycle stage of the UHPC bridge design using GaBi construction materials database.

\begin{tabular}{|c|c|c|c|}
\hline Material & Quantity & Unit & Delivery Proces \\
\hline Bitumen & 96.58 & $\mathrm{~kg}$ & Bitumen at refinery, production mix, at refinery, from crude oil, DE \\
\hline Crushed sand $(0 / 2)$ & 900.00 & $\mathrm{~kg}$ & $\begin{array}{l}\text { Limestone, crushed stone fines (Grain size 0/4) (EN15804 A1-A3), } \\
\text { production mix, at plant, technology mix, grain size 0/4, DE }\end{array}$ \\
\hline Diesel & 44.61 & $\mathrm{~kg}$ & $\begin{array}{l}\text { Diesel mix at filling station, consumption mix, at filling station, } \\
\text { from crude oil and bio components, } 8.37 \text { wt. } \% \text { bio components, DE }\end{array}$ \\
\hline Electricity & 315.20 & MJ & $\begin{array}{l}\text { Electricity grid mix } 1 \mathrm{kV}-60 \mathrm{kV} \text {, consumption mix, to consumer, } \mathrm{AC} \text {, } \\
\text { technology } \mathrm{mix}, 1 \mathrm{kV}-60 \mathrm{kV}, \mathrm{DE}\end{array}$ \\
\hline Light fuel oil & 2.3 & $\mathrm{~kg}$ & $\begin{array}{l}\text { Light fuel oil at refinery (EN15804 B6), production mix, at refinery, } \\
\text { from crude oil, } 0.1 \text { wt. } \% \text { sulphur, DE }\end{array}$ \\
\hline $\begin{array}{c}\text { Liquefied } \\
\text { petroleum gas }\end{array}$ & 2.64 & $\mathrm{~kg}$ & $\begin{array}{l}\text { Liquefied Petroleum Gas (LPG) (EN15804 B6), production mix, at } \\
\text { refinery, Mix of } 70 \% \text { propane and } 30 \% \text { butane, DE }\end{array}$ \\
\hline $\begin{array}{l}\text { Melted asphalt, } \\
\text { integrated }\end{array}$ & 1728.00 & $\mathrm{~kg}$ & $\begin{array}{l}\text { Mastic asphalt (EN15804 A1-A3), production mix, at plant, } \\
\text { technology mix, } 2400 \mathrm{~kg} / \mathrm{m} 3, \mathrm{DE}\end{array}$ \\
\hline $\begin{array}{l}\text { Stone mastic } \\
\text { asphalt }\end{array}$ & 28.80 & $\mathrm{t}$ & $\begin{array}{l}\text { Stone mastic asphalt SMA (EN15804 A1-A3), production mix, at } \\
\text { plant, technology mix, SMA, DE }\end{array}$ \\
\hline $\begin{array}{l}\text { Transporting } \\
\text { capacity }\end{array}$ & 3.00 & $\mathrm{tkm}$ & $\begin{array}{l}\text { Delivery van (EN15804 A4), production mix, at plant, technology } \\
\text { mix, diesel driven, cargo, DE }\end{array}$ \\
\hline $\begin{array}{l}\text { Transporting } \\
\text { capacity }\end{array}$ & 83.70 & $\mathrm{tkm}$ & $\begin{array}{l}\text { Small truck (EN15804 A4), production mix, at plant, technology } \\
\text { mix, DE }\end{array}$ \\
\hline $\begin{array}{l}\text { Transporting } \\
\text { capacity }\end{array}$ & 1782.00 & $\mathrm{tkm}$ & $\begin{array}{l}\text { Road train (EN15804 A4), production mix, at plant, technology mix, } \\
\text { DE }\end{array}$ \\
\hline
\end{tabular}




\section{Appendix C.5. Life Cycle Inventory for C1-C3 Life Cycle Stages}

Table A32. Calculation of the required fuels for the demolition of the structure, module C1-C3, CC bridge design.

\begin{tabular}{|c|c|c|c|c|c|}
\hline Measure & Construction Machine & $\begin{array}{c}\text { Spec. } \\
\text { Consumption }\end{array}$ & Quantity & Needs & Energy Carrier \\
\hline \multirow{4}{*}{ Discontinuance } & Milling machine & $2.54 \mathrm{~L} / \mathrm{m}^{3}$ & $23.67 \mathrm{~m}^{3}$ & $60.12 \mathrm{~L}$ & Diesel \\
\hline & Excavator with peeling & $0.2 \mathrm{~L} / \mathrm{m}^{2}$ & & $122.54 \mathrm{~L}$ & Diesel \\
\hline & device & $0.13 \mathrm{~L} / \mathrm{m}^{2}$ & $612.70 \mathrm{~m}^{2}$ & $79.65 \mathrm{~L}$ & Propane \\
\hline & Demolition machines & $17.60 \mathrm{~L} / \mathrm{m}^{3}$ & $360.00 \mathrm{~m}^{3}$ & $6336.00 \mathrm{~L}$ & Diesel \\
\hline \multirow{5}{*}{ Editing } & Treatment facility & $13.00 \mathrm{MJ} / \mathrm{t}$ & \multirow{2}{*}{$131.06 \mathrm{t}$} & $1703.78 \mathrm{MJ}$ & Diesel \\
\hline & ireatment racinty & $10.00 \mathrm{MJ} / \mathrm{t}$ & & $1310.60 \mathrm{MJ}$ & Electricity \\
\hline & Dredgers & $0.30 \mathrm{~L} / \mathrm{m}^{3}$ & \multirow{3}{*}{$360.00 \mathrm{~m}^{3}$} & $108.00 \mathrm{~L}$ & Diesel \\
\hline & Wheel loader & $0.60 \mathrm{~L} / \mathrm{m}^{3}$ & & $216.00 \mathrm{~L}$ & Diesel \\
\hline & Concrete preparation plant & $18.26 \mathrm{MJ} / \mathrm{m}^{3}$ & & $6573.60 \mathrm{MJ}$ & Electricity \\
\hline
\end{tabular}

Table A33. Calculation of the required transports when demolishing the structure, module C2, CC bridge design.

\begin{tabular}{|c|c|c|c|c|c|c|c|}
\hline \multirow{2}{*}{ Material } & \multirow{2}{*}{ Quantity } & \multirow{2}{*}{$\begin{array}{c}\text { Mean of } \\
\text { Transportation }\end{array}$} & Rides & Workload & Distance & Payload & \multirow{2}{*}{$\begin{array}{l}\text { Transport } \\
\text { Capacity }\end{array}$} \\
\hline & & & (Quantity) & $(\%)$ & $(\mathrm{km})$ & (t) & \\
\hline \multirow{2}{*}{$\begin{array}{l}\text { Covering + } \\
\text { sealing }\end{array}$} & \multirow{2}{*}{$63.06 \mathrm{t}$} & \multirow[b]{2}{*}{ Road Train } & 4 & 50 & 30 & 27 & \multirow[b]{2}{*}{$1863.00 \mathrm{tkm}$} \\
\hline & & & 2 & 15 & 30 & 27 & \\
\hline $\begin{array}{l}\text { Concrete } \\
\text { fracture }\end{array}$ & $864.00 \mathrm{t}$ & Road Train & 64 & 50 & 30 & 27 & $25,920.00 \mathrm{tkm}$ \\
\hline \multirow{2}{*}{ Steel } & \multirow{2}{*}{$68.00 \mathrm{t}$} & \multirow{2}{*}{ Road Train } & 4 & 50 & 30 & 27 & \multirow{2}{*}{$2025.00 \mathrm{tkm}$} \\
\hline & & & 2 & 25 & 30 & 27 & \\
\hline
\end{tabular}

Table A34. Life cycle processes for modules C1-C3 of the CC bridge design using GaBi construction materials database.

\begin{tabular}{cccl}
\hline Medium & Quantity & Einheit & \multicolumn{1}{c}{ Delivery Process } \\
\hline Diesel & 5822.14 & $\mathrm{~kg}$ & $\begin{array}{l}\text { Diesel mix at filling station, consumption mix, at filling station, } \\
\text { from crude oil and bio components, 8.37 wt.\% bio components, DE }\end{array}$ \\
\hline Electricity & 7884.20 & $\mathrm{MJ}$ & $\begin{array}{l}\text { Electricity grid mix 1 kV-60 kV, consumption mix, to consumer, AC, } \\
\text { technology mix, 1 kV-60 kV, DE }\end{array}$ \\
\hline $\begin{array}{c}\text { Liquefied } \\
\text { petroleum gas }\end{array}$ & 0.16 & $\mathrm{~kg}$ & $\begin{array}{l}\text { Liquefied Petroleum Gas (LPG) (EN15804 B6), production mix, } \\
\text { at refinery, Mix of 70\% propane and 30\% butane, DE }\end{array}$ \\
\hline $\begin{array}{c}\text { Transporting } \\
\text { capacity }\end{array}$ & $29,808.00$ & $\mathrm{tkm}$ & $\begin{array}{l}\text { Road train (EN15804 A4), production mix, at plant, } \\
\text { technology mix, DE }\end{array}$ \\
\hline
\end{tabular}

Table A35. Calculation of the required fuels when demolishing the structure, module C1-C3, UHPC bridge design.

\begin{tabular}{|c|c|c|c|c|}
\hline Construction Machine & $\begin{array}{c}\text { Specific } \\
\text { Consumption }\end{array}$ & Quantity & Need & Energy Carrier \\
\hline Milling machine & $2.54 \mathrm{~L} / \mathrm{m}^{3}$ & $12.81 \mathrm{~m}^{3}$ & $32.54 \mathrm{~L}$ & Diesel \\
\hline Demolition machines & $\begin{array}{l}17.60 \mathrm{~L} / \mathrm{m}^{3} \\
35.20 \mathrm{~L} / \mathrm{m}^{3}\end{array}$ & $\begin{array}{c}205.00 \mathrm{~m}^{3} \\
61.60 \mathrm{~m}^{3}\end{array}$ & $\begin{array}{l}3608.00 \mathrm{~L} \\
2168.32 \mathrm{~L}\end{array}$ & $\begin{array}{l}\text { Diesel } \\
\text { Diesel }\end{array}$ \\
\hline Treatment facility & $\begin{array}{l}13.00 \mathrm{MJ} / \mathrm{t} \\
10.00 \mathrm{MJ} / \mathrm{t}\end{array}$ & $93.42 \mathrm{t}$ & $\begin{array}{c}1214.46 \mathrm{MJ} \\
934.20 \mathrm{MJ}\end{array}$ & $\begin{array}{c}\text { Diesel } \\
\text { Electricity }\end{array}$ \\
\hline $\begin{array}{c}\text { Excavator, NC } \\
\text { Wheel loader, NC } \\
\text { Concrete preparation plant NC }\end{array}$ & $\begin{array}{c}0.30 \mathrm{~L} / \mathrm{m}^{3} \\
0.60 \mathrm{~L} / \mathrm{m}^{3} \\
18.26 \mathrm{MJ} / \mathrm{m}^{3}\end{array}$ & $205.00 \mathrm{~m}^{3}$ & $\begin{array}{c}61.50 \mathrm{~L} \\
123.00 \mathrm{~L} \\
3743.30 \mathrm{MJ}\end{array}$ & $\begin{array}{c}\text { Diesel } \\
\text { Diesel } \\
\text { Electricity }\end{array}$ \\
\hline $\begin{array}{c}\text { Excavator, UHPC } \\
\text { Wheel loader, UHPC } \\
\text { Concrete preparation plant UHPC }\end{array}$ & $\begin{array}{c}0.43 \mathrm{~L} / \mathrm{m}^{3} \\
0.60 \mathrm{~L} / \mathrm{m}^{3} \\
21.21 \mathrm{MJ} / \mathrm{m}^{3}\end{array}$ & $61.60 \mathrm{~m}^{3}$ & $\begin{array}{c}26.49 \mathrm{~L} \\
36.96 \mathrm{~L} \\
1306.54 \mathrm{MJ}\end{array}$ & $\begin{array}{c}\text { Diesel } \\
\text { Diesel } \\
\text { Electricity }\end{array}$ \\
\hline
\end{tabular}


Table A36. Calculation of the required transports when demolishing the structure, module C2, UHPC bridge design.

\begin{tabular}{|c|c|c|c|c|c|c|c|}
\hline \multirow{2}{*}{ Material } & \multirow{2}{*}{ Quantity } & \multirow{2}{*}{$\begin{array}{c}\text { Mean of } \\
\text { Transportation }\end{array}$} & Rides & Workload & Distance & Payload & \multirow{2}{*}{$\begin{array}{l}\text { Transport } \\
\text { Capacity }\end{array}$} \\
\hline & & & (Quantity) & $(\%)$ & $(\mathrm{km})$ & (t) & \\
\hline \multirow{2}{*}{ Surface } & \multirow[b]{2}{*}{$31.52 \mathrm{t}$} & \multirow{2}{*}{ Road Train } & 2 & 50 & 30 & 27 & \multirow{2}{*}{$972.00 \mathrm{tkm}$} \\
\hline & & & 2 & 10 & 30 & 27 & \\
\hline \multirow{2}{*}{$\begin{array}{l}\text { CC Concrete } \\
\text { demolishing }\end{array}$} & \multirow[b]{2}{*}{$492.00 \mathrm{t}$} & \multirow{2}{*}{ Road Train } & 36 & 50 & 30 & 27 & \multirow{2}{*}{$14,742.00 \mathrm{tkm}$} \\
\hline & & & 2 & 10 & 30 & 27 & \\
\hline \multirow{2}{*}{ UHPC } & \multirow{2}{*}{$148.00 \mathrm{t}$} & \multirow{2}{*}{ Road Train } & 10 & 50 & 30 & 27 & \multirow{2}{*}{$4455.00 \mathrm{tkm}$} \\
\hline & & & 2 & 25 & 30 & 27 & \\
\hline \multirow{2}{*}{$\begin{array}{c}\text { Concrete } \\
\text { demolishing }\end{array}$} & \multirow{2}{*}{$61.90 \mathrm{t}$} & \multirow{2}{*}{ Road Train } & 4 & 50 & 30 & 27 & \multirow{2}{*}{$1863.00 \mathrm{tkm}$} \\
\hline & & & 2 & 15 & 30 & 27 & \\
\hline
\end{tabular}

Table A37. Life cycle inventory of C1-C3 life cycle stage of the UHPC bridge design using GaBi construction materials database.

\begin{tabular}{cccl}
\hline Flow & Quantity & Unit & \multicolumn{1}{c}{ Delivery Process } \\
\hline Diesel & 5146.58 & $\mathrm{~kg}$ & $\begin{array}{l}\text { Diesel mix at filling station, consumption mix, at filling station, from } \\
\text { crude oil and bio components, 8.37 wt.\% bio components, DE }\end{array}$ \\
\hline Electricity & 5984.04 & $\mathrm{MJ}$ & $\begin{array}{l}\text { Electricity grid mix } 1 \mathrm{kV}-60 \mathrm{kV}, \text { consumption mix, to consumer, AC, } \\
\text { technology mix, 1 kV-60 kV, DE }\end{array}$ \\
\hline
\end{tabular}

\section{References}

1. Huang, L.; Krigsvoll, G.; Johansen, F.; Liu, Y.; Zhang, X. Carbon emission of global construction sector. Renew. Sustain. Energy Rev. 2018, 81, 1906-1916. [CrossRef]

2. Fischedick, M.; Görner, K.; Thomeczek, M. $\mathrm{CO}_{2}$ : Abtrennung, Speicherung, Nutzung: Ganzheitliche Bewertung im Bereich von Energiewirtschaft und Industrie $\left[\mathrm{CO}_{2}\right.$ : Separation, Storage, Use: Holistic Assessment in the Field of Energy Industry and Industry]; Springer: Berlin/Heidelberg, Germany, 2015. [CrossRef]

3. Di Maria, A.; Salman, M.; Dubois, M.; van Acker, K. Life cycle assessment to evaluate the environmental performance of new construction material from stainless steel slag. Int. J. Life Cycle Assess. 2018. [CrossRef]

4. Huntzinger, D.N.; Eatmon, T.D. A life-cycle assessment of Portland cement manufacturing: Comparing the traditional process with alternative technologies. J. Clean. Prod. 2009, 17, 668-675. [CrossRef]

5. Sameer, H.; Bringezu, S. Life cycle input indicators of material resource use for enhancing sustainability assessment schemes of buildings. J. Build. Eng. 2018. [CrossRef]

6. European Commision. Raw Materials Scoreboard-European Innovation Partnership on Raw Materials; European Commision: Brussels, Belgium, 2016. [CrossRef]

7. Gerbens-Leenes, P.W.; Hoekstra, A.Y.; Bosman, R. The blue and grey water footprint of construction materials: Steel, cement and glass. Water Resour. Ind. 2018, 19, 1-12. [CrossRef]

8. Schorcht, F.; Kourti, I.; Scalet, B.M.; Roudier, S.; Sancho, L.D. Best available techniques (BAT) for the Production of Cement. Lime Magnes. Oxide 2013. [CrossRef]

9. Schneider, M. Process technology for efficient and sustainable cement production. Cem. Concr. Res. 2015, 78, 14-23. [CrossRef]

10. Miller, S.A.; John, V.M.; Pacca, S.A.; Horvath, A. Carbon dioxide reduction potential in the global cement industry by 2050. Cem. Concr. Res. 2018, 114, 115-124. [CrossRef]

11. Lim, J.; Raman, S.; Safiuddin, M.; Zain, M.; Hamid, R. Autogenous Shrinkage, Microstructure, and Strength of Ultra-High Performance Concrete Incorporating Carbon Nanofibers. Materials 2019, 12, 320. [CrossRef] [PubMed]

12. Liu, K.; Yu, R.; Shui, Z.; Li, X.; Ling, X.; He, W.; Yi, S.; Wu, S. Effects of pumice-based porous material on hydration characteristics and persistent shrinkage of Ultra-High Performance Concrete (UHPC). Materials 2018, 12, 11. [CrossRef] [PubMed]

13. Wetzel, A.; Umbach, C.; Fehling, E.; Middendorf, B. Multifunctional prefabricated walls made of UHPC and foam concrete. Insights Innov. Struct. Eng. Mech. Comput. 2016, 86, 143-148. [CrossRef] 
14. Schmidt, M.; Fehling, E.; Fröhlich, S.; Thiemicke, J. Sustainable Building with Ultra-High Performance Concrete-Results of the German Priority Programme 1182 funded by Deutsche Forschungsgemeinschaft (DFG); Kassel University Press: Kassel, Germany, 2014. Available online: http://www.upress.uni-kassel.de/ katalog/abstract.php?978-3-86219-480-3 (accessed on 12 March 2019).

15. Wille, K.; Naaman, A.E.; Parra-Montesinos, G.J. Ultra-High Performance Concrete with compressive strength exceeding $150 \mathrm{MPa}$ (22 ksi): A simpler way. ACI Mater. J. 2011, 108, 34-46.

16. Roux, N.; Andrade, C.; Sanjuán, M.A. Experimental Study of Reactive Powder Concretes (RPC). J. Mater. Civil Eng. ASCE 1996, 8, 1-6. [CrossRef]

17. Hansen, T.B.; Aarup, B. Engineering challenges in international application of UHPFRC. Concr. Eng. Int. 2015, 13 .

18. MShafieifar, O.; Farzad, M.; Azizinamini, A. Experimental and numerical study on mechanical properties of Ultra High Performance Concrete (UHPC). Constr. Build. Mater. 2017, 156, 402-411. [CrossRef]

19. Schmidt, M.; Bunje, K.; Dehn, F.; Droll, K.; Fehling, E.; Greiner, S.; Horvarth, J.; Kleen, E.; Müller, C.; Reineck, K.-H.; et al. Sachstandsbericht Ultrahochfester Beton [Progress Report Ultra-High-Performance Concrete]. DAFSTB-HEFT 561. Beuth, 2008. Available online: https:/ /www.beuth.de/de/publikation/heft561-dafstb / 107880416 (accessed on 26 October 2018).

20. Schmidt, C. Konstruktion und Wirtschaftlichkeit von Whitetopping aus Hochleistungsbeton für Fahrbahnen Whitetopping of Asphalt and Concrete Pavements with Thin Layers of Ultra High Performance Concrete-Construction and Economic Efficiency [Construction and Efficiency of Whitetopping of High Performance Concrete for Roadways Whitetopping of Asphalt and Concrete Pavements with Ultra Thin Films Concrete-Construction and Economic Efficiency]. 2012. Available online: http:/ /www.uni-kassel.de/ upress / online/frei/978-3-86219-342-4.volltext.frei.pdf (accessed on 26 October 2018).

21. Bringezu, S. Possible Target Corridor for Sustainable Use of Global Material Resources. Resources 2015, 4, 25-54. [CrossRef]

22. Miller, S.A.; Monteiro, P.J.M.; Ostertag, C.P.; Horvath, A. Comparison indices for design and proportioning of concrete mixtures taking environmental impacts into account. Cem. Concr. Compos. 2016, 68, 131-143. [CrossRef]

23. Celik, K.; Meral, C.; Gursel, A.P.; Mehta, P.K.; Horvath, A.; Monteiro, P.J.M. Mechanical properties, durability, and life-cycle assessment of self-consolidating concrete mixtures made with blended portland cements containing fly ash and limestone powder. Cem. Concr. Compos. 2015, 56, 59-72. [CrossRef]

24. Miller, S.A.; Monteiro, P.J.M.; Ostertag, C.P.; Horvath, A. Concrete mixture proportioning for desired strength and reduced global warming potential. Constr. Build. Mater. 2016, 128, 410-421. [CrossRef]

25. Colangelo, F.; Forcina, A.; Farina, I.; Petrillo, A. Life Cycle Assessment (LCA) of Different Kinds of Concrete Containing Waste for Sustainable Construction. Buildings 2018, 8, 70. [CrossRef]

26. Association of German Engineers (VDI). VDI 4800 Part 2 Resource Efficiency Evaluation of Raw Material Demand; VDI: Düsseldorf, Germany, 2018.

27. Boulay, A.M.; Bare, J.; Benini, L.; Berger, M.; Lathuillière, M.J.; Manzardo, A.; Margni, M.; Motoshita, M.; Núñez, M.; Pastor, A.V.; et al. The WULCA consensus characterization model for water scarcity footprints: Assessing impacts of water consumption based on available water remaining (AWARE). Int. J. Life Cycle Assess. 2018, 23, 368-378. [CrossRef]

28. Gursel, A.P.; Masanet, E.; Horvath, A.; Stadel, A. Life-cycle inventory analysis of concrete production: A critical review. Cem. Concr. Compos. 2014, 51, 38-48. [CrossRef]

29. Association of German Engineers (VDI). Resource Efficiency Methodological Principles and Strategies; VDI 4800 Part 1; VDI: Düsseldorf, Germany, 2016.

30. Association of German Engineers (VDI). Ressourceneffizienz Bewertung des Rohstoffaufwands [Resource Efficiency_Evaluation of the Use of Raw Materials]; VDI 4800 Part 2 Draft; VDI: Düsseldorf, Germany, 2016.

31. BMUB (German Federal Ministry for the Environment Nature Conservation Building and Nuclear Safety). German Resource Effciency Programme II/Programme for the Sustainable Use and Conservation of Natural Resources [Brochure], Berlin. 2016. Available online: http:/ /www.bmub.bund.de/en/service/publications / broschueren-bestellen/\#cr1 (accessed on 14 October 2018).

32. EN 15804. Sustainability of Construction Works—Environmental Product Declarations-Core Rules for the Product Category of Construction Products, German version EN 15804; CEN: Brussels, Belgium, 2012. 
33. European Environment Agency (EEA). More from Less-Material Resource Efficiency in Europe. 2015 Overview of Policies, Instruments and Targets in 31 Countries; EEA: København, Denmark, 2016. [CrossRef]

34. Stengel, T.; Schießl, P. Life Cycle Assessment of Uhpc Bridge Constructions: Sherbrooke Footbridge, Kassel Gärtnerplatz Footbridge and Wapello Road Bridge. Archit. Civ. Eng. Environ. 2009, 1, 109-118.

35. Randl, N.; Steiner, T.; Ofner, S.; Baumgartner, E.; Mészöly, T. Development of UHPC mixtures from an ecological point of view. Constr. Build. Mater. 2014, 67, 373-378. [CrossRef]

36. Hester, J.; Miller, T.R.; Gregory, J.; Kirchain, R. Actionable insights with less data: Guiding early building design decisions with streamlined probabilistic life cycle assessment. Int. J. Life Cycle Assess. 2018, 23, 1903-1915. [CrossRef]

37. Finkbeiner, M.; Inaba, A.; Tan, R.B.H.; Christiansen, K.; Klüppel, H.J. The new international standards for life cycle assessment: ISO 14040 and ISO 14044. Int. J. Life Cycle Assess. 2006, 11, 80-85. [CrossRef]

38. Bringezu, S.; Potocnik, J.; Schandl, H.; Lu, Y.; Ramaswami, A.; Swilling, M.; Suh, S. Multi-scale governance of sustainable natural resource use-Challenges and opportunities for monitoring and institutional development at the national and global level. Sustainability 2016, 8, 778. [CrossRef]

39. DIN EN 206. Beton-Festlegung, Eigenschaften, Herstellung und Konformität [Concrete-Specification, Performance, Production and Conformity]; Deutsche Fassung EN 206:2013+A1:2016 [German Version EN 206:2013+A1:2016]; Beuth Verlag GmbH: Berlin, Germany, 2017. [CrossRef]

40. Becke, A.; Reiners, J.; Sülün, C. Erläuterungen zu den Umweltproduktdeklarationen für Beton [Explanations to the Environmental Product Declarations of Concrete]; InformationsZentrum Beton GmbH: Düsseldorf, Germany, 2014. Available online: https://betonshop.de/media/wysiwyg/PDF/epd_broschuere_2014.pdf (accessed on 12 March 2019).

41. BS EN 197-1:2011. Cement. Composition, Specifications and Conformity Criteria for Common Cements; DIN: Berlin, Germany, 2011.

42. Eyerer, P.; Hans-Wolf, R. (Eds.) Ökologische Bilanzierung von Baustoffen und Gebäuden: Wege zu einer ganzheitlichen Bilanzierung (BauPraxis). Ecological balancing of building materials and buildings: ways to a holistic balancing (construction practice; InformationsZentrum Beton GmbH: Erkrath, Germany, 2000.

43. Thinkstep GaBi, Extension Database XIV: Construction Materials. Available online: http: / / www.gabi-software.com/support/gabi/gabi-database-2018-lci-documentation/extension-databasexiv-construction-materials / (accessed on 7 April 2018).

44. GreenDelta, Download / openLCA.org. 2018. Available online: http://www.openlca.org/download/ (accessed on 26 February 2018).

45. Ecoinvent, Ecoinvent Version 3. Available online: https://www.ecoinvent.org/database/database.html (accessed on 12 August 2018).

46. German Association Deutsche Bauchemie (DBC). Betonzusatzmittel und Umwelt [Concrete Admixtures and the Environment], Deutsche Bauchemie e.V., Frankfurt am Main. 2016. Available online: https: //deutsche-bauchemie.de/fileadmin/sites/public/dbc/publikationen/DBC_214_SB-D-2016.pdf (accessed on 12 March 2019).

47. Stengel, T.; Schießl, P. Sustainability Analysis of UHPC Using Inventory Analysis and Impact Assessment. University of Kassel: Kassel, Germany, 2014. Available online: http:/ /www.upress.uni-kassel.de/katalog/ abstract.php?978-3-86219-480-3 (accessed on 12 March 2019).

48. German Ready-Mixed Concrete Association, Ökobilanzielle Baustoffprofile für Transportbeton [Life Cycle Assessment of Construction Materials for Ready-Mix Concrete]. Düsseldorf. 2007. Available online: https: / / www.transportbeton.org/about-btb / (accessed on 12 March 2019).

49. Dorer, C.; Hahn, J. Energetische Optimierung der Betonherstellung im Transportbetonwerk—Bestandsaufnahme und Ableitung von Optimierungspotenzialen [Energetic Optimization of Concrete Production in the Ready-Mix Concrete Plant-Inventory and Derivation of Optimization Poten. 2015. Available online: https:/ / www.transportbeton.org/fileadmin/user_upload/Abschlussbericht_Energetische_Optimierung2015-03-06-.pdf (accessed on 12 March 2019).

50. Heyn, S.; Mettke, A. Ökologische Prozessbetrachtungen-RC-Beton (Stofffluss, Energieaufwand, Emissionen) [Ecological Process Considerations-RC Concrete (Material flow, energy consumption, emissions)]; Brandenburgische Technische Universität Cottbus: Cottbus, Germany, 2010. 
51. Quack, D.; Liu, R. Ökobilanz Betondecken Eine Vergleichende Analyse von Spannbeton-Fertigdecken mit Halbfertigteildecken und Massivdecken aus Ortbeton [Life Cycle Assessment of Concrete slab. A Comparative Analysis of Pre-Stressed Concrete Slabs with Semi-Finished Slabs and in-situ concrete slabs]; Öko-Institut e.V.: Freiburg, Germany, 2010.

52. Bundesverband der Deutschen Transportbetonindustrie e.V. German Federation of the Ready-Mixed Concrete, Jahresbericht 2016/2017 [26/5000 Annual Report 2016/2017]; Bundesverband der Deutschen Transportbetonindustrie e.V. (BTB): Berlin, Germany, 2017.

53. Toppel, C.O. Technische und Ökonomische Bewertung Verschiedener Abbruchverfahren im Industriebau [Technical and Economic Evaluation of Various Demolition Methods in Industrial Construction]. University of Darmstadt, 2003. Available online: http:/ / tuprints.ulb.tu-darmstadt.de/439/1/dissertation.pdf (accessed on 12 March 2019).

54. European Commission. ILCD Handbook: Interational Reference Life Cycle Data System, Recommendations for Life Cycle Impact Assessment in the European Context; European Commission: Brussels, Belgium, 2011. [CrossRef]

55. Myhre, G.; Shindell, D.; Bréon, F.-M.; Collins, W.; Fuglestvedt, J.; Huang, J.; Koch, D.; Lamarque, J.-F.; Lee, D.; Mendoza, B.; et al. Anthropogenic and Natural Radiative Forcing; Cambridge University Press: Cambridge, UK, 2013. [CrossRef]

56. Ritthoff, M.; Rohn, H.; Liedtke, C. Calculating MIPS: Resource Productivity of Products and Services; Wuppertal Institute for Climate, Environment and Energy: Wuppertal, Germany, 2002. Available online: http:/ / epub. wupperinst.org/frontdoor/index/index/docId/1577 (accessed on 12 March 2019).

57. Mostert, C.; Ostrander, B.; Bringezu, S.; Kneiske, T. Comparing Electrical Energy Storage Technologies Regarding Their Material and Carbon Footprint. Energies 2018, 11, 3386. [CrossRef]

58. Saurat, M.; Ritthoff, M. Calculating MIPS 2.0. Resources 2013, 2, 581-607. [CrossRef]

59. Murguia, D.I. Global Area Disturbed and Pressures on Biodiversity by Large-Scale Metal Mining. 2015. Available online: http:/ / www.uni-kassel.de/upress/online/OpenAccess/978-3-7376-0040-8.OpenAccess. pdf (accessed on 12 March 2019).

60. Hoppe, W. Systemanalytischer Vergleich rohstofflicher Nutzungsoptionen von $\mathrm{CO}_{2}$ bei Verwendung regenerativer Energien unter besonderer Berücksichtigung der Ressourceneffizienz und Treibhausgasbilanz [System-Analytical Comparison of Feedstock Utilization Options of $\mathrm{CO}_{2}$ ]; Kassel University: Kassel, Germany, 2017.

61. WU. materialflows.net: Indicators on the Economy-Wide Level. Vienna University of Economics and Business, Institute for Ecological Economics, 2016. Available online: http://www.materialflows. net/materialflowsnet/background/accounting/indicators-on-the-economy-wide-level/ (accessed on 25 June 2017).

62. ISO 14046. Water Footprint_Principles, Requirements and Guidelines; ISO: Geneva, Switzerland, 2014.

63. Brühwiler, E.; Fehling, E.; Bunje, K.; Pelke, E. Design of an innovative composite bridge combining reinforced concrete with Ultra-High Performance Fibre Reinforced Concrete, IABSE Symp. Report. Int. Assoc. Bridge Struct. Eng. 2007, 93, 17-24. [CrossRef]

64. Schmidt, M.; Brühwiler, E.; Fehling, E.; Denarié, E.; Leutbecher, T.; Teichmann, T. Mix design and properties of Ultra-High Performance Fibre Reinforced Concrete for the construction of a composite UHPFRC-Concrete Bridge. Int. Assoc. Bridge Struct. Eng. 2007, 466-476.

65. Lünser, H. Ökobilanzen im Brückenbau-Eine Umweltbezogene, Ganzheitliche Bewertung [Life Cycle Assessments in Bridge Construction-An Environmental, Holistic Assessment]; Birkhäuser: Basel, Switzerland, 2013.

66. Fehling, E.; Schmidt, M.; Walraven, J.; Leutbecher, T.; Fröhlich, S. Ultra-High Performance Concrete UHPC: Fundamentals, Design, Examples; John Wiley \& Sons: Hoboken, NJ, USA, 2014.

67. ISO 14040. Environmental Management_Life Cycle Assessment_Principles and Framework; ISO: Geneva, Switzerland, 1997. [CrossRef]

68. Ngo, T. Application of UHPC in Long Span Bridge Design. 2016. Available online: https:/ / repository.tudelft. $\mathrm{nl} /$ islandora/object/uuid:128b5606-28b3-46ec-bb78-4830f7319eee (accessed on 12 March 2019).

69. Blesl, M.; Alois, K. Energieeffizienz in der Industrie [Energy Efficiency in Industry]; Springer: Berlin, Germany, 2013.

(C) 2019 by the authors. Licensee MDPI, Basel, Switzerland. This article is an open access article distributed under the terms and conditions of the Creative Commons Attribution (CC BY) license (http://creativecommons.org/licenses/by/4.0/). 